\title{
8 \\ THE PERILOUS POLLING OF SINGLE SEATS
}

\author{
Murray Goot ${ }^{1}$
}

For a contest that was to be decided, many insisted, by hand-to-hand combat in various seats, we might have expected commentators on the progress of the 2019 election campaign to have focused on the polling in particular seats rather than on the national polls. But they did not. While there were, as there long has been, many fewer national polls than single-seat pollsmostly, though not entirely, in seats classified officially as 'marginal' - when it came to anticipating the outcome, the scorecards from the single-seat polls certainly did not displace the traditional focus on the national polls.

Given the media's interest in contests where Coalition MPs were under threat from Independents or the Greens, and in contests where Coalition candidates were mounting credible challenges against Independent MPs, we might also have expected the media to have commissioned polls in a number of these seats. But only in Mayo (SA), where Rebekha Sharkie (Centre Alliance) was facing a Liberal challenge to regain the seat, was there any media-sponsored polling in seats of this kind.

\footnotetext{
1 My thanks to Kevin Bonham, William Bowe; David Briggs, Angela Smith and Campbell White at YouGov Galaxy; David Bednall, Andrew Bunn, Jessica Elgood at Ipsos; Carol Johnson, Malcolm Mackerras, Gary Morgan of Roy Morgan Research; Marian Simms, Mark Textor of the C|T Group; James Stewart from uComms; John Utting of Utting Research; and a number of journalists who would probably prefer to remain unnamed. The author is a panel member of the Inquiry into the Performance of the Opinion Polls at the 2019 Australian Federal Election, established by the Association of Market and Social Research Organisations. The views expressed in this chapter, however, are his own. The research was supported by the Australian Research Council under DP150102968.
} 
At the same time, we might have expected polls in single seats, with their smaller samples, to have performed more poorly than the national polls. While many did perform more poorly, almost as many performed better. The single-seat polls that proved the best guides, on average, were those conducted in New South Wales and in Victoria; in New South Wales, they were more accurate than the national polls. The worst polls-much worse than could be explained by sample size alone-were the single-seat polls conducted in Queensland and Western Australia, which were the States where the Coalition did best. It was in these States that the national polls may have been the poorest guides as well.

In this chapter-in addition to noting how many single-seat polls there were, which seats were polled and how well the polls did in comparison with the national polls-I ask: who commissioned the polls in single seats (the major media groups), when were they conducted (mostly, towards the end of the campaign and not more than once) and which market research firms conducted them (just two; one, arguably, with a conflict of interest). I set out what pollsters reported about their respondents' vote choice: first preferences and two-party preferred-a measure that was pollster-constructed. I look at how closely the polls came to forecasting the results in individual seats, either in terms of their proximity to the final figures (a statistician's measure) or in terms of picking the winners (a journalist's concern). That 'the polls' got it wrong is a judgement based, for the most part, on the national polls. Would the view of the polls' performance be different were it based on the single-seat polls?

I also review various accounts of where the single-seat polls went wrong: late deciders, samples too small, the 'undecided' ignored and margins of sampling error not adequality acknowledged. I conclude by asking how these polls could have performed better; and, in commissioning and publishing them, how the media could have better managed their risks. The answers to both questions suggest that not a lot is likely to change.

\section{The polls: For whom, where and when}

During election campaigns, polls help sell newspapers. If they can afford it - and most metropolitan mastheads can-the press, and occasionally a television network, commission polls of various kinds and promote them as 'exclusives'. During the 2019 campaign, the results of 18 national polls were published, each with its own estimate of how Australians 
would vote. Six were commissioned by The Australian, the national daily owned by News Corp Australia; two by the Australian Financial Review (AFR), Sydney Morning Herald and Melbourne Age, which were formerly owned by Fairfax but are now owned by Nine Entertainment; and two by News Corp's metropolitan mastheads the Daily Telegraph (NSW), Herald-Sun (Victoria), The Courier-Mail (Queensland), The Advertiser (South Australia) and the Mercury (Tasmania). The other eight were conducted by market research firms with no media contracts: five by Roy Morgan Research and three by Essential Research, which released its results to The Guardian (see Table 8.1).

Over the same period, News Corp, Seven West Media and Network 10 released, in varying detail, the results of 43 single-seat polls conducted in 35 seats (Appendix Tables A8.1-A8.3); of these, 32 were marginal seats. Ten days after the election had been called, Newspoll ran polls for The Australian in Pearce (WA), Herbert (Qld), Deakin (Vic.) and Lindsay (NSW). A week or so out from the election, on 9-11 May, it followed up with polls in Herbert and Lindsay and two other seats, Corangamite (Vic.) and Bass (Tas.). Mid-campaign, YouGov Galaxy conducted polls for Seven West Media in three West Australian seats (Cowan, Pearce and Swan), following up on the final Tuesday and Wednesday of the campaign with polls in these seats and two others (Hasluck and Stirling). On Monday and Tuesday of the final week of the campaign, YouGov Galaxy conducted polls in 11 'crucial seats'-Dickson, Flynn, Forde, Herbert and Leichhardt (Qld); Deakin, Higgins and La Trobe (Vic.); and Gilmore, Macquarie and Reid (NSW) - for the News Corp Australia Network. The results of these polls were released one by one, hour by hour, from 10 am Eastern Standard Time the day before the election (News Corp Australia Network 2019), a pattern designed to encourage interested readers to take out a subscription to the relevant masthead. First—and last-out of the blocks was uComms, commissioned by News Corp's Geelong Advertiser, shortly after the election was called, to test opinion in the very marginal seat of Corangamite (Vic.) in which the newspaper circulated (Jefferson 2019, the poll mistakenly attributed to ReachTEL), and to test opinion for Network 10's The Project, shortly before the election, in 12 seats (including Corangamite) drawn from all six States. Every poll was a robo-poll, using interactive voice recognition (IVR), with questions asked on the telephone, but not by a live interviewer, and answered by someone in the household, though not necessarily the person from whom the pollster wants to hear. 
MORRISON'S MIRACLE

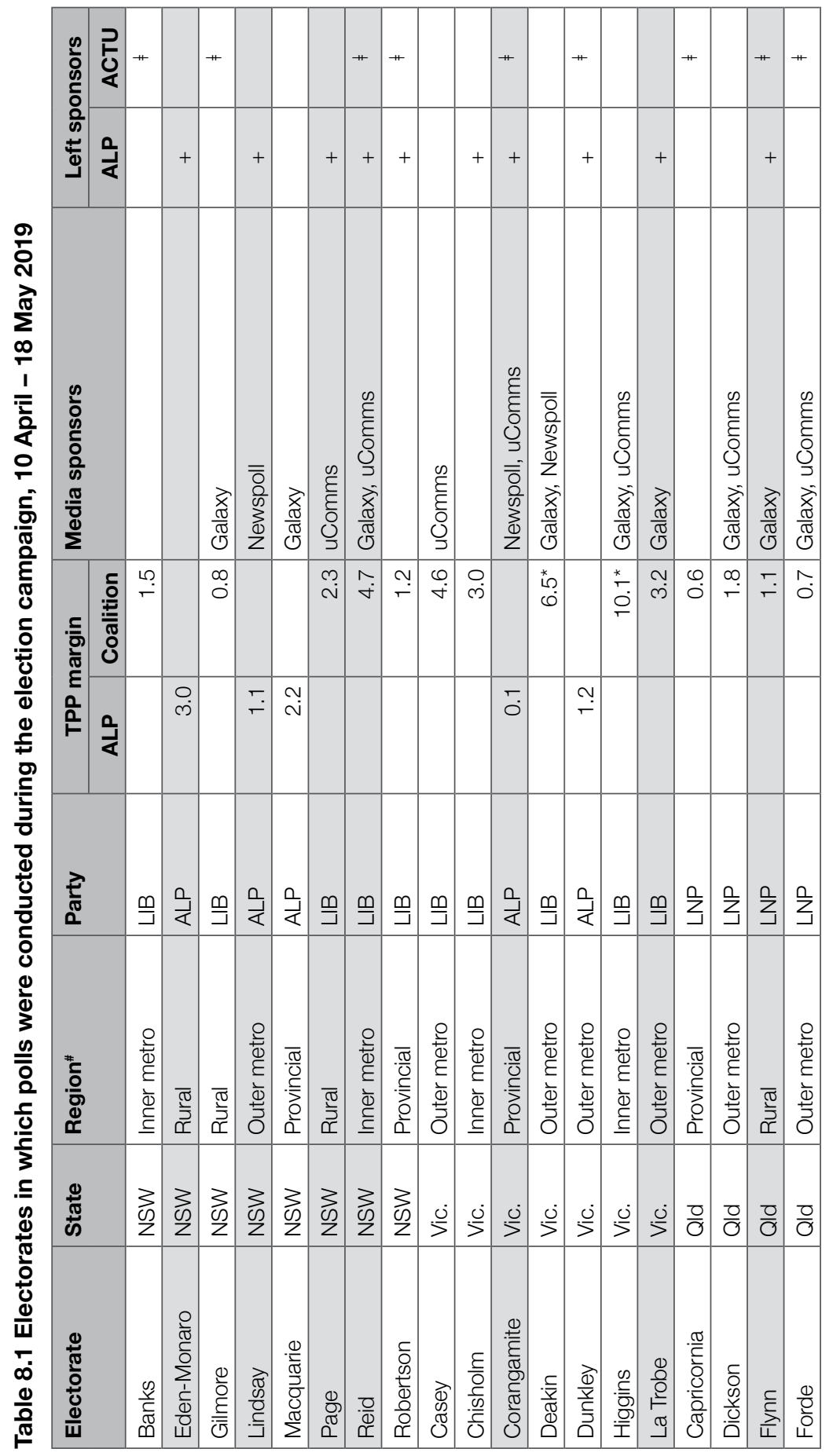




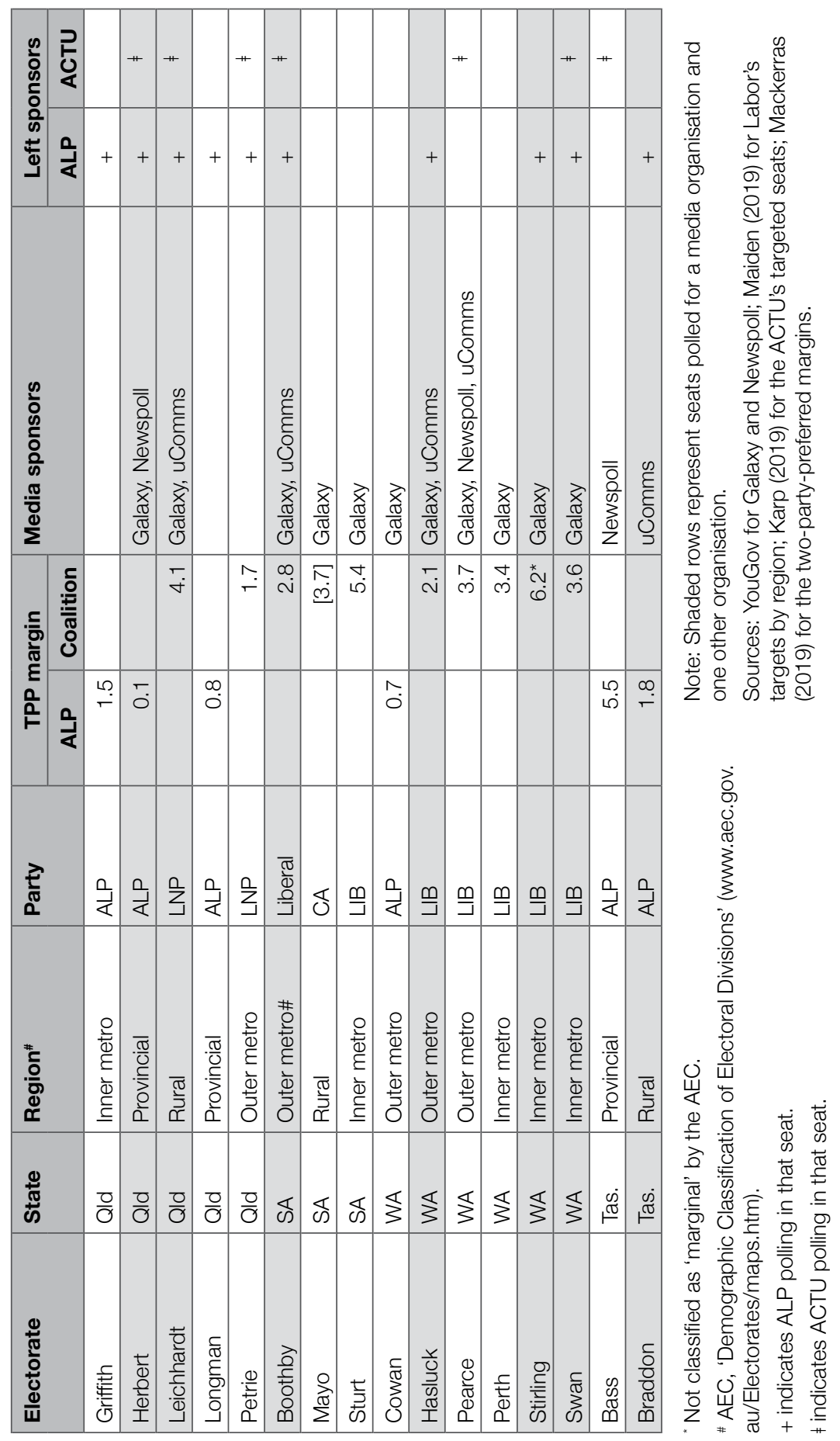


Having one firm (Galaxy, in 2016; YouGov, in 2019) using identical methods and responsible for two brands-Newspoll and YouGov Galaxy-raised potential conflicts of interest. In seats polled by both, could the results published under one brand be very different from those published under the other? Three seats-Deakin (Vic.), Herbert (Qld) and Pearce (WA) - were polled and sometimes repolled by both Newspoll and YouGov Galaxy (Table 8.1). But they were polled by one, followed by the other, either two weeks apart (Pearce) or four weeks apart (Deakin, Herbert). This may have avoided questions being raised about inconsistent results, but where the results were consistent it risked raising the question of herding. That few seats were polled by both Newspoll and YouGov Galaxy could be read in different ways: reassuringly, as an outcome that minimised any conflict; worryingly, as a sign of how the conflict constrained seat selection; or as sheer coincidence, determined not by two not-very-independent polling operations, but by two entirely separate clients.

Of greater concern to The Australian was its discovery-though not until after the election - that YouGov Galaxy had been doing Labor's single-seat polling as well. The pollster's failure to disclose its involvement with Labor meant that journalists who thought they were cross-checking Newspoll's figures with an independent source (Labor) were doing nothing of the kind. Liberal sources expressed their disbelief in the figures Newspoll was producing for The Australian since they were at odds with the figures the Crosby Textor Group (C|T) was generating for the Liberals. Labor sources, on the other hand, were happy to confirm that the single-seat figures Newspoll was reporting were very like their own. Journalists either did not ask who was doing Labor's polling or were not told.

In terms of which outlets commissioned polls and from which pollsters, the contrast with 2016 was marked. In 2016, no polls were commissioned by Seven West Media or the News Corp Australia network, and uComms did not exist. News Corp's metropolitan mastheads commissioned single-seat polls of their own, either from YouGov Galaxy or from ReachTEL; the latter had also polled for 7 News and Fairfax Media (subsequently, part of Nine Entertainment). In 2019, ReachTEL conducted no polls; in 2016, it conducted polls in 21 seats. In 2019, Morgan undertook no single-seat polling; in 2016, it had conducted polls in 31 seats (Goot 2018: 117-22). 
As remarkable as the decline-from 47 in 2016 to 26-in the number of seats polled was the decline in the number seats polled more than once, which was down from 18 (including three polled as many as four times) in 2016 to 11 (only one polled four times). Long gone were the days when, courtesy of one pollster or another, a seat might be polled up to eight times (Goot 2009: 123). Filling the gaps, journalists paid increasing attention to what they could glean about the state of play from the political parties, interest groups or other 'activists'.

The decline in the number of single-seat polls the media commissioned, and the reduction in the number of seats they polled more than once, reflects cost pressures and concerns about the credibility of single-seat polls. Costs-a perennial consideration-had been pressing on media managers with increasing force, notwithstanding that robo-polls are cheap compared with traditional methods. Credibility, by contrast, was a relatively new concern. Whereas journalists not so long ago would express regret at the inability of their organisations to fund more single-seat polls, now they were more inclined to qualify their reports by referring to the unreliability of such polls (for the most forensic analysis, see Jackman and Mansillo 2018: 149).

\section{The seats}

Of the seats requiring a swing of less than 6 percentage points to change-the AEC's definition of a marginal seat-21 were held by the Coalition and 22 by Labor (including Corangamite and Dunkley, which were notionally Labor as a result of a redistribution). Yet the seats that were polled were not drawn in equal numbers from the two sides. Nor would one expect them to be. The election, after all, was a contest that Labor was expected to win-an expectation due in no small measure to an uninterrupted string of national polls that showed Labor ahead. Consequently, the number of Liberal seats polled (23) was twice the number of Labor seats (11) — the ratio being constant for YouGov Galaxy, Newspoll and uComms. The number of Liberal seats polled at least twice (eight) was four times the corresponding number of Labor seats.

Though most of the seats polled were marginal, they were not always the most marginal. Seats polled for Seven West Media included two that required swings of close to 4 percentage points but excluded one (Perth) that required a swing closer to 3 percentage points. The Australian 
organised polls in the third most marginal Liberal seat in Western Australia; the most marginal Labor seats in Queensland, Victoria and New South Wales; a Liberal seat in Victoria (Deakin) that was not classified as marginal; and a seat (Bass) that was Labor's second most marginal, not its most marginal, seat in Tasmania. News Corp chose Labor's most marginal seat in Queensland (Herbert) plus the Coalition's eighth most marginal (Leichhardt) and three of its four most marginal seats, but not its most marginal (Capricornia); three Liberal seats in Victoria, only one of them (La Trobe) a marginal seat; and in New South Wales, Labor's second most marginal seat (Macquarie) plus the Liberals' most marginal (Gilmore) and fourth most marginal seat (Reid). Network 10's The Project chose Page - the only National Party seat to figure in any of the single-seat polling - and Reid, which were, respectively, the second and fourth most marginal Coalition seats in New South Wales; Casey and Higgins (as well as Corangamite), which were the third and 13th most marginal Liberal seats in Victoria; Dickson, Forde and Leichhardt, which were the second, fourth and eighth most marginal LNP seats in Queensland; Hasluck and Pearce, the most marginal and third most marginal Liberal seats in Western Australia; and Boothby and Braddon, the most marginal Liberal and Labor seats in South Australia and Tasmania, respectively.

Notable for their absence were Warringah (NSW), where former prime minister Tony Abbott was being challenged (successfully) by Zali Steggall (Independent); and Kooyong (Vic.), where the Treasurer, Josh Frydenberg (Liberal), was being challenged (unsuccessfully) by Julian Burnside (the Greens). Also ignored were Wentworth (NSW), where Kerryn Phelps (Independent) was being challenged (successfully) by Dave Sharma (Liberal); and Indi (Vic.), where Helen Haines (Independent), hoping to succeed Cathy McGowan (Independent), was being challenged (unsuccessfully) by Steve Martin (Liberal). These contests (discussed by Curtin and Sheppard, Chapter 18, this volume) involved Independent candidates who were women.

The National Party seats ignored included some considered to be at risk from independents—chief among them: New England (NSW), where former deputy prime minister Barnaby Joyce was being challenged (unsuccessfully) by Adam Blakester (Independent); and Cowper (NSW), where the newly pre-selected National Party candidate Patrick Conaghan was being challenged (unsuccessfully) by the former member for Lyne, Rob Oakeshott (Independent). 
Across the largest States, the polls were relatively thinly spread; across the smaller States, the coverage was greater. In the most populous States, the number of seats polled-New South Wales (eight), Victoria (seven), Queensland (nine) and Western Australia (six)—was roughly the same. Across the remainder-South Australia (three) and Tasmania (two) - it was numerically smaller but disproportionately large. Inner metropolitan and outer metropolitan seats, each of which accounted for 26 per cent of the seats in the outgoing House, were slightly underrepresented in the media polls; each made up about 30 per cent of the seats. Underrepresented, too, were rural seats (18 per cent) that made up one-quarter of the outgoing House. Overrepresented were provincial seats: 30 per cent of the seats polled, but only half that proportion on the floor of the House (see Table 8.1). If seat selection is any guide, the media thought this election was not going to be decided only in the metropolitan suburbs, let alone in the metropolitan suburbs of the largest States.

Sharing an assumption that this was an election at which more Liberal than Labor seats would fall, there was considerable overlap between the seats the media polled and the seats polled by the ALP and the ACTU. (The Liberal Party's list of target seats was tightly guarded). Of all 20 seats polled by the ALP, 70 per cent were also polled for the media; of the 16 seats polled by the ACTU, the proportion polled for the media was almost the same. Of the 26 seats polled by either the ALP or the ACTU, less than 40 per cent were the same (Table 8.1) - a division of labour or a disagreement among allies about which seats offered the greater prospect?

\section{The results}

How well did the polls do in the single seats chosen by the media? The standard way of answering this question-standard for a statistician, if not for a journalist-is to look at the size of the differences between what the polls reported and what the election results showed. Standard for a journalist, if not for a statistician, is to look at whether the polls predicted the winners. We can run these tests for Newspoll and YouGov Galaxy, but we cannot run them for uComms since it produced no estimate of the first preferences, seat by seat, that took account of how the 'undecided' might divide, nor a seat-by-seat estimate of the two-party-preferred vote. 
Looking only at those polls completed in the final week of the campaignthe 16 conducted by YouGov Galaxy and the four by Newspoll-the errors seem grim. Two-party preferred, the mean difference between the polls' estimates and the actual results was 4.1 percentage points for YouGov Galaxy and 3.0 percentage points for Newspoll; the median differences-3.8 percentage points (YouGov Galaxy) and 2.9 percentage points (Newspoll)—were very similar (Table 8.2).

Table 8.2 Differences between the polls' estimate of party support and the actual vote in single seats, two-party preferred, Galaxy and Newspoll (percentage points)

\begin{tabular}{|l|l|r|r|r|}
\hline Pollster & Fieldwork $^{*}$ & \multicolumn{1}{|c|}{ Seats } & \multicolumn{1}{c|}{ Mean } & \multicolumn{1}{c|}{ Median } \\
\hline YouGov Galaxy & 13-15 May & 16 & 4.1 & 3.8 \\
\hline Newspoll & 9-12 May & 4 & 3.0 & 2.9 \\
\hline
\end{tabular}

' Polls concluded more than 10 days before the election are excluded.

Sources: See Appendix Table A8.1 for YouGov Galaxy; Table A8.2 for Newspoll.

In Queensland, as Table 8.3 shows, the errors were considerably higher, 6 percentage points, on average; in Victoria (2.6), Tasmania (2.4) and New South Wales (1.7), they were markedly lower; and in Western Australia (4.3), they sat around the mean. In almost every case, the polls underestimated the Coalition's share of the two-party-preferred vote. Ipsos, the only polling organisation to have released State-by-State breaks from its final national poll, showed a similar pattern, with its biggest underestimate of the Coalition's two-party-preferred vote being for Tasmania (7.5 percentage points), followed by Queensland (5.7), Western Australia (4.6), South Australia and the Northern Territory (about 3.1), New South Wales (1.1) and Victoria (where it overestimated, not underestimated, the Coalition's two-party-preferred vote by 1.1 percentage points).

Table 8.3 Mean overestimates (+) or underestimates (-) of the two-partypreferred and first-preference vote in single seats, by party, Galaxy and Newspoll (percentage points)

\begin{tabular}{|l|r|r|r|r|r|r|r|r|}
\hline \multicolumn{2}{|c|}{ Seats } & \multicolumn{1}{c|}{ TPP } & \multicolumn{6}{c|}{ First preferences } \\
\hline State & No. & (Coalition) & ALP & Coalition & Greens & UAP & PHON & Other \\
\hline WA & 5 & -4.3 & +6.0 & -2.7 & -2.3 & +1.2 & -1.6 & -0.6 \\
\hline Qld & 6 & -6.0 & +5.7 & -2.1 & -1.4 & +3.2 & -5.2 & -2.9 \\
\hline Vic. & 4 & -2.6 & +0.8 & -2.5 & +1.8 & +1.7 & - & -0.6 \\
\hline NSW & 4 & -1.7 & +0.5 & -2.1 & -1.5 & +2.1 & - & -0.8 \\
\hline Tas. & 1 & -2.4 & +4.3 & -2.3 & -0.5 & -0.9 & - & -0.6 \\
\hline
\end{tabular}

- PHON had no candidates in seats polled in Victoria, New South Wales and Tasmania. Sources: See Appendix Table A8.1 for YouGov Galaxy; and Table A8.2 for Newspoll. 
The main source of the differences between the polls' estimates and the election results, not surprisingly, was the polls' estimates of Labor's first preferences - and, to a lesser degree, the first preferences won by Clive Palmer's UAP. As Table 8.3 shows, polls conducted in single seats overestimated Labor's share of the vote-most egregiously in Western Australia (6 percentage points, on average), Queensland (5.7) and Tasmania (4.3), though hardly at all in Victoria (0.8) or New South Wales (0.5). The polls overestimated support for the UAP in Queensland (3.2 percentage points), but also in New South Wales (2.1), Victoria (1.7) and Western Australia (1.2). Conversely, the same polls underestimated support for the Coalition (the size of the errors being fairly uniform), the Greens (except in Victoria, where it overestimated them) and PHON_especially in Queensland. The contrast with 2016, when the polls underestimated Labor's support and overestimated support for the Coalition (Jackman and Mansillo 2018: 146), is striking.

Were the pollsters caught out by not polling closer to the election? If any of them thought this, none of them said it-and with good reason. Despite polling earlier, Newspoll (9-12 May) was closer to the mark in its seats than was YouGov Galaxy (13-15 May) in its seats (see also Jackman and Mansillo 2018: 150). Indeed, in two South Australian seats (Boothby and Mayo) polled before the final week of the campaign, YouGov Galaxy got closer to the mark than it did in most of the seats it polled during the final week (Appendix Table A8.1). During the final seven days of the campaign, only Newspoll conducted more than one national poll. It showed no tightening - if anything, the reverse (Benson 2019c).

After the election, at least one pollster wondered whether the (national) polls had erred in assuming the 'don't knows' would split along the same lines as other respondents (Lewis 2019). Did the 'don't knows' break disproportionately in favour of the Coalition? Evidence from two national post-election surveys suggests they did not. A JWS poll shows virtually no difference in the proportion of Coalition (39 per cent) and Labor respondents (37 per cent) who said they had decided on their vote in the final week, including on election day (JWS 2019: 10-11). Even if we ignore the fact that 49 per cent of Greens respondents also said they had decided late, these figures do not point to late deciders disproportionately favouring the Coalition. An Essential poll shows those who made up their mind on election day favoured the Coalition (38 per cent) over Labor (27 per cent). From this, The Guardian inferred that the Coalition did especially well from late deciders (Murphy 2019). But the figures showing 
that, of those who voted either Coalition or Labor at the last minute, 58 per cent voted Coalition and 42 per cent voted Labor almost exactly match the 41.4:33.3 division (equivalent to 55:45) in the share of the vote recorded by the Coalition and Labor at the election (Goot 2019).

Had pollsters found some defensible way of allocating most of the 'don't knows' to the Coalition, they would have reduced the differences between their figures and the election results in both the single-seat polls and the national polls. But to have really made a difference-to have closed the gap by 1 or 2 percentage points - the 'don't knows' would have needed to be much bigger than 1 or 2 per cent. In the 16 single-seat polls produced by YouGov Galaxy, 10 reported a 'don't know' figure of just 1 or 2 per cent. Of the four single-seat polls conducted by Newspoll, only one reported a figure for the 'don't knows'; it was 1 per cent. True, the figures for the 'undecided' published by uComms averaged 5 per cent (Appendix Table A8.3), but these derived from responses to uComms' initial question ("Which of the following parties will receive your firstpreference vote?'), not from responses to this question plus the followup asked of the 'undecided' about the party or individual they had 'even a slight leaning' towards—a 'leaner' having preceded the figures published by YouGov Galaxy and Newspoll with which the uComms figures need to be compared.

Whether, ideally, 'don't knows' should be pushed-asked a 'leaner'is a separate matter. Is reducing the 'undecided' to no more than 1 or 2 per cent of the sample really credible, when none of the national polls had a final 'undecided' of less than 4 per cent and at a time when so many respondents appeared to be uncertain about their choice? According to the post-election poll conducted by Essential, 26 per cent of voters did not make up their mind until the final week(s) of the campaign (Murphy 2019). JWS Research (2019) estimated that the proportion who made up their mind in the final week was as high as 40 per cent.

A quite different way of looking at the performance of the polls is to consider how accurately they anticipated who would win each seat. 'We were the most accurate in showing the seats likely to be won or lost in Queensland', said David Briggs, managing director of YouGov Galaxy, and in 'showing that Labor were not picking up seats they needed there' (quoted in Tabakoff 2019). However, since: 1) Briggs ran the only company polling single seats and producing figures that could be compared with the election results (uComms did not allocate the 
'undecided'); 2) YouGov Galaxy had the Coalition ahead in only two of the four Queensland seats in which it polled; and 3) Labor not only failed to win seats in Queensland, but also lost two seats (in only one of which either YouGov Galaxy or Newspoll polled), it is difficult to see Briggs's claim amounting to much.

Neither YouGov Galaxy nor Newspoll made as bad a fist of it as they might have made. None of the seats polled by YouGov Galaxy and only one of the seats (Bass) polled by Newspoll had Labor winning seats they were not going to win, and neither YouGov Galaxy nor Newspoll had the Coalition losing seats they were not going to lose. The problem with YouGov Galaxy was having five of its 16 seats on an estimated two-party preferred of 50:50 - seats that the Coalition went on to win (as Appendix Table A8.1 shows) either comfortably (Swan, 52.8 per cent; La Trobe, 54.5 per cent) or handsomely (Hasluck, 55.2 per cent; Herbert, 58.4 per cent; and Forde, 58.6 per cent).

\section{Conclusion}

Not for the first time in an Australian election, many thought the contest would be decided by local battles in individual seats (see, for example, Simms 1997). Not for the first time, some thought they discerned in this something new; one journalist wrote of a 'new hyper-localism' in political campaigning (Irvine 2019). And not for the first time in an Australian election, the single-seat polling proved neither particularly accurate in estimating vote shares (first preferences or the two-party preferred) nor especially good at forecasting which party in the various seats would win. Since elections allow polls to showcase their value, failing to come up with a tolerably good estimate of the vote shares or failing to predict a number of the winners is no small thing.

What might be done to improve them? One suggestion—dating from the early days of polling - is that pollsters, and the press, do more to emphasise the fact that polls provide estimates, not precise measures. At a meeting of Gallup Poll directors held after the 1948 American polling debacle, the director of the Italian Institute of Public Opinion announced that at the next election he would 'give the figures \pm 3 '; if the figure in the poll was 50 , he would report it as lying in the range 47-53. Piero Luzzatto Fegiz was intending to draw his readers' attention not to a poll's sampling error, but to the vagaries of electoral turnout (Gallup 1949: 8)—a source 
of non-sampling error. No matter. Would Australian readers have been happy to be told that the 50:50 results YouGov Galaxy reported in so many seats did not mean they were all on a 'knife-edge', but that there was a 95 per cent probability (with a sample size of about 500) that the two-party vote was somewhere between 54.5 (ALP) and 45.5 (Coalition), which would be a comfortable win for Labor, and 45.5 (ALP) and 54.5 (Coalition), which would be a comfortable win for the Coalition? Hardly. A poll on the eve of an election that does not double as a predictive device is a poll that has little commercial value. There is a reason for 'margins of error' being buried in the fine print, for the meaning of the phrase not being clarified and for the possible sources of non-sampling error passing without mention.

Thinking about ways of handling the 'don't knows', other than by assuming they will divide in much the same way as other respondents, makes more sense. At the same meeting of the 'Gallup family', George Gallup stressed that at the next American election:

He would say 'The decided will vote in this way ...' and then devote two or three paragraphs to explaining the problem of the undecided vote- - e.g. how it could be reduced by a 'leaning' question and how the rest could be distributed-e.g. (a) in the same proportions as the rest of the vote, or by past preference.

He might even say to the reader:

'Here are the latest figures: this is what the (sampled) electorate said 7 days before the election day. What's your guess what will happen? Which party will gain votes, which one [will] lose, what will the net result be?' ... In other words, let the reader actively participate in the game so that it isn't Dr Gallup but the reader himself who will get the laurels ... or eat crow. (Gallup 1949: 5-6)

Reflecting on the performance of the Australian polls 70 years later, Peter Lewis, managing director of Essential, suggested that pollsters could have published a set of percentages for each party and the 'don't knows' that added to 100 rather than a set of percentages that added to 100 excluding the 'don't knows' (Lewis 2019). Whether pollsters would have been better advised to report the 'don't knows' after the 'leaner' or without the 'leaner', Lewis did not say. Publishing a set of percentages for each party and the 'don't knows' without a 'leaner', seat by seat, that added to 100 
was precisely what $\mathrm{uComms}$ had done. However, while having pollsters report figures in this way might guarantee they were never wrong, it would hardly allow them to claim that they ever got it right.

The media, too, is in the prediction business-a business parasitic on the polls. Much media coverage is framed in terms of which of the parties is ahead, which is behind and whether the gap is opening or closing. It follows that few would want to publish seat-by-seat figures of the kind uComms produced for Channel 10; uComms did not produce a set of individual seat figures that excluded the 'don't knows', though it did publish a twoparty-preferred figure for the 12 seats overall (putting the Coalition ahead 52:48) after pressing the 'don't knows' with a 'leaner' and excluding any who remained 'undecided'. In these seats, the Coalition would prevail, $54.5: 45.5$. Underestimating the Coalition's vote by 2.5 percentage points (54.5, not 52) put uComms on a par with the underestimates made by the national polls (Appendix Table A8.4).

Pollsters who do not predict the winner are asked by the media to explain - or, in the case of Ipsos (arguably the best of the national polls), do not have their contract renewed. Gallup thought the public's belief that pre-election polling had but one purpose- 'to pick the winner'was 'a misconception' (Gallup 1949: 5). But if that was the case, it was a misconception pollsters knew they lived by-one they could never hope to correct and still expect to have newspaper contracts at election time. Not that a pollster has ever been sacked on the basis of their single-seat polls, only on the basis of their nationwide polls.

On this occasion, the single-seat polls were never sufficiently extensive, consistent or reliable to override the message delivered by the national polls-all of them having delivered the same message for a long time. At the beginning of the final week of the campaign, The Australian, under the heading 'Marginals tumble into Coalition ledger but Labor clings to winning lead', published the results of its final single-seat polls (Benson 2019a). On election day, under the heading 'Voters' bob each way', it published the results of its final national poll. 'Despite the halfpoint break towards Labor in the final week', Simon Benson (2019c) reported, 'party strategists on both sides believe the swing is patchy and "hand-to-hand" battles in about 20 seats will decide the election'. The two headlines, and accompanying stories, captured much that was problematic in the way the polls were covered: the vision, however prescient, of marginal seats tumbling to the Coalition when only four 
had been polled, two of them showing Labor ahead; the idea that polls could measure changes of 0.5 percentage point, despite a footnote about a sampling error of \pm 1.8 percentage points, which, as it happens, was precisely the size of Newspoll's median error between 1993 and 2010 (Goot 2012: 106); and the suggestion that a lead in the polls meant a lead in the seats-something that had not held true in two of the previous 10 elections, in 1998 and 1990.

That pollsters are not well enough resourced to do their job well seems clear. They may need to improve their sampling frames or change sampling modes, boost their response rates (currently in single figures for IVR), especially among the disengaged, and attend to the way they weight their data (including education, and possibly religion, might help). To do this, they will need to ask more questions. They should include questions that better inform their readers, including questions that allow them to distinguish between respondents firmly committed to their vote choice and respondents who are not. Getting the polls off the hook may also require a change in the way journalists understand and report the polls. At the risk of adding another poor prediction to an already large pile, my guess is that most of these problems are unlikely to be resolved. Unlike pollsters with their predictions, however, I would be happy to be wrong.

\section{References}

Benson, Simon. 2019a. 'Kingmaker: Palmer's campaign hits pay dirt'. The Australian, 23 April.

Benson, Simon. 2019b. 'Marginals tumble into Coalition ledger but Labor clings to winning lead'. The Australian, 13 May.

Benson, Simon. 2019c. 'Voters' bob each way'. Weekend Australian, 18-19 May.

Coorey, Phillip. 2019. 'Labor clings to shrinking lead', Australian Financial Review, 17 May.

Crowe, David. 2019. 'Labor retains the edge but Coalition claws back ground', Sydney Morning Herald, 17 May.

Essential Media. 2019. Essential Report. www.essentialvision.com.au/category/ essentialreport.

Gallup. 1949. 'Gallup Conference: Paris 3, 4, 5 \& 6 Sept. 1949'. Minutes. Roy Morgan Papers. 
Goot, Murray. 2009. 'Getting it Wrong While Getting It Right: The Polls, the Press and the 2007 Australian Election'. Australian Cultural History 27(2): 115-33. doi.org/10.1080/07288430903164769.

Goot, Murray. 2012. 'To the second decimal point: How the polls vied to predict the national vote, monitor the marginals and second-guess the Senate'. In Julia 2010: The Caretaker Election, edited by Marian Simms and John Wanna, 85-110. Canberra: ANU E Press. doi.org/10.22459/J2010.02.2012.06.

Goot, Murray. 2018. 'National polls, marginal seats and campaign effects'. In Double Disillusion: The 2016 Federal Election, edited by Anika Gauja, Peter Chen, Jennifer Curtin and Juliet Pietsch, 107-32. Canberra: ANU Press. doi.org/10.22459/DD.04.2018.05.

Goot, Murray. 2019. 'Did late deciders confound the polls?'. Inside Story, 19 September. insidestory.org.au/did-late-deciders-confound-the-polls/.

Ipsos. 2019. Fairfax Ipsos Poll: National Poll (12-15 May 2019). 16 May. Sydney: Ipsos Australia.

Irvine, Jessica. 2019. 'Dunny deeds buy your votes, but not dirt cheap'. Sydney Morning Herald, 16 May.

Jackman, Simon and Luke Mansillo. 2018. 'The campaign that wasn't: Tracking public opinion over the 44th Parliament and the 2016 election campaign'. In Double Disillusion: The 2016 Federal Election, edited by Anika Gauja, Peter Chen, Jennifer Curtin and Juliet Pietsch, 133-56. Canberra: ANU Press. doi.org/10.22459/DD.04.2018.06.

Jefferson, Andrew. 2019. 'Sarah Henderson on track to retain Corangamite according to new poll figures'. Geelong Advertiser, 20 April. www.geelongadvertiser.com. $\mathrm{au} /$ news/geelong/sarah-henderson-on-track-to-retain-corangamite-accordingto-new-poll-figures/news-story [page discontinued].

JWS. 2019. Post-election survey shows detail behind Saturday's surprising election result. Sydney: JWS Research. jwsresearch.com/2019/05/24/post-electionsurvey-shows-detail-behind-saturdays-surprising-election-result/.

Karp, Paul. 2019. "Breaking down the myths": Blue-ribbon Liberal seats on unions' long target list'. The Guardian, 20 April. www.theguardian.com/ australia-news/2019/apr/20/breaking-down-the-myths-blue-ribbon-liberalseats-on-unions-long-target-list.

Lewis, Peter. 2019. 'As pollsters, we are rightly in the firing line after the Australian election. What happened?'. The Guardian, 21 May. www.theguardian.com/ commentisfree/2019/may/21/as-pollsters-we-are-rightly-in-the-firing-lineafter-the-australian-election-what-happened. 
Mackerras, Malcolm. 2019. 'Federal Pendulum2019election result'. Unrepresentative Swill, [Blog]. www.malcolmmackerras.com/mackerras-pendulums.

Maiden, Samantha. 2019. 'Newspoll pollster also behind ALP's flawed election research'. The New Daily, 20 May. thenewdaily.com.au/news/election-2019/ 2019/05/20/Labor-polls-election-loss.

Murphy, Katharine. 2019. 'Post-election research shows 11\% of voters made up their mind on polling day'. The Guardian, 4 June. www.theguardian.com/ australia-news/2019/jun/04/post-election-research-shows-11-of-voters-madeup-their-mind-on-polling-day.

News Corp Australia Network. 2019. 'Federal election 2019: New polls in ten crucial electorates to reveal likely winner'. PerthNow, 17 May. www.perthnow. com.au/news/australia/election-2019-opinion-polls-in-ten-crucial-electoratesto-reveal-likely-election-winner-ng-e42b7b35ca2e3a9a3af7dd2aaf381566.

Roy Morgan. 2019. 'ALP regains initiative with a week to go: ALP 52\% cf. L-NP 48\%', 14 May, Finding No. 7975. www.roymorgan.com/findings/7975-alpregains-initiative-with-a-week-to-go-201905140553.

Simms, Marian. 1997. “'All politics is local politics”: Candidates and campaigning in the 1996 election'. In The Politics of Retribution: The 1996 Federal Election, edited by Clive Bean, Marian Simms, Scott Bennett and John Warhurst, 4754. Sydney: Allen \& Unwin.

Tabakoff, Nick. 2019. 'The diary'. The Australian, 15 July. 
8. THE PERILOUS POLLING OF SINGLE SEATS

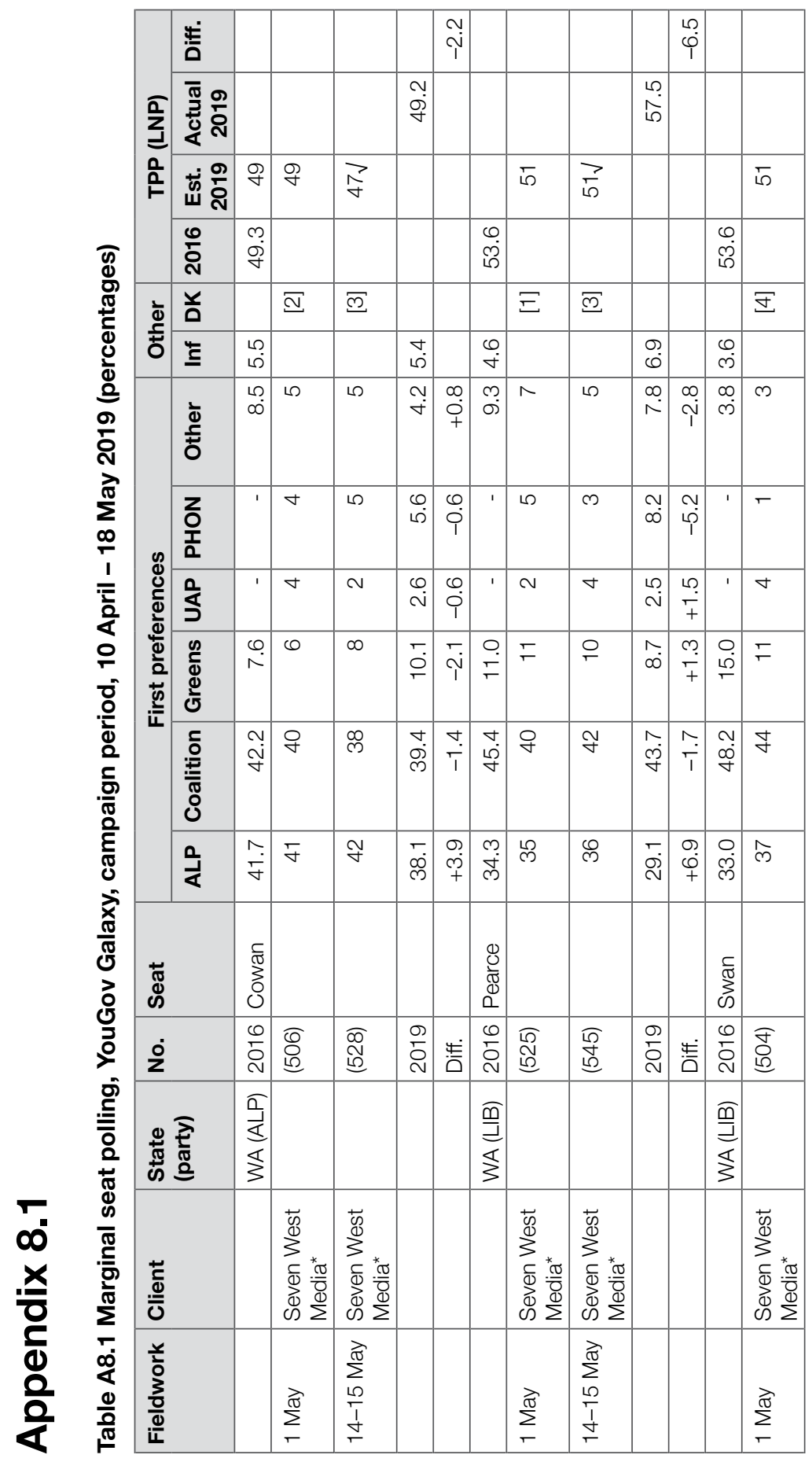


MORRISON'S MIRACLE

\begin{tabular}{|c|c|c|c|c|c|c|c|c|c|c|c|c|c|c|c|c|c|}
\hline & 杗 & & & $\begin{array}{l}\infty \\
\stackrel{\sim}{\uparrow} \\
\uparrow\end{array}$ & & & & $\begin{array}{l}\stackrel{N}{p} \\
\stackrel{p}{p}\end{array}$ & & & & & & & & $\begin{array}{l}\hat{p} \\
\dot{p}\end{array}$ & \\
\hline 畜 & 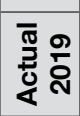 & & $\begin{array}{l}\infty \\
\\
i\end{array}$ & & & & $\begin{array}{l}N \\
\stackrel{n}{0}\end{array}$ & & & & & $\begin{array}{l}\infty \\
\dot{+} \\
\dot{T}\end{array}$ & & & 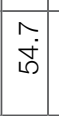 & & \\
\hline$\frac{a}{2}$ & ن் & 8 & & & & 8 & & & & $\overrightarrow{i n}$ & $\begin{array}{l}\infty \\
1 \\
1 \\
1 \\
1\end{array}$ & & & $\overrightarrow{i n}$ & & & \\
\hline & ลั & & & & $\overline{\mathrm{N}}$ & & & & $\overline{\dot{\phi}}$ & & & & $\stackrel{\Lambda}{\dot{L}}$ & & & & $\frac{0}{i}$ \\
\hline Ф & 号 & $\sigma$ & & & & $\bar{\Xi}$ & & & & $\widetilde{\mathbb{N}}$ & & & & $\Xi$ & & & \\
\hline ठే & $\underline{\underline{\Xi}}$ & & $\begin{array}{l}\infty \\
\dot{0} \\
\dot{0}\end{array}$ & & $\begin{array}{l}\stackrel{\circ}{*} \\
\stackrel{+}{*}\end{array}$ & & $\begin{array}{l}+ \\
\dot{0}\end{array}$ & & $\bar{i}$ & & $\begin{array}{l} \\
\dot{\sigma} \\
\dot{\sigma}\end{array}$ & . & $\stackrel{\nabla}{\dot{m}}$ & & $\underset{\dot{*}}{+}$ & & $\begin{array}{l}\nabla \\
\dot{0}\end{array}$ \\
\hline & 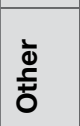 & 10 & $\begin{array}{l}\dot{\varphi} \\
\dot{\omega}\end{array}$ & 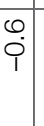 & $\bar{r}$ & 0 & $\hat{0}$ & $\hat{i}$ & $\begin{array}{l}0 \\
\dot{0}\end{array}$ & $\nabla$ & $\hat{\dot{\rho}}$ & $\begin{array}{l}0 \\
0 \\
+\end{array}$ & $\begin{array}{l}\text { 足 } \\
\stackrel{0}{\circ}\end{array}$ & $\sim$ & $\begin{array}{l}\overrightarrow{0} \\
\dot{0}\end{array}$ & $\stackrel{⿱ 亠 乂}{p}$ & $\begin{array}{l}\dot{\varphi} \\
\dot{\sigma}\end{array}$ \\
\hline$\infty$ & 음 & $N$ & $\stackrel{+}{\sim}$ & $\begin{array}{l}\stackrel{0}{0} \\
\dot{T}\end{array}$ & ' & 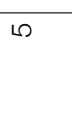 & $\begin{array}{l}m \\
\dot{D}\end{array}$ & $\begin{array}{l}0 \\
0 \\
0 \\
1\end{array}$ & 1 & $\sim$ & $\stackrel{\varphi}{\omega}$ & $\begin{array}{l}\stackrel{0}{\leftarrow} \\
\stackrel{1}{T}\end{array}$ & I & $\infty$ & $\begin{array}{c}\stackrel{N}{i ்} \\
\stackrel{0}{0}\end{array}$ & & $\stackrel{N}{\stackrel{N}{N}}$ \\
\hline 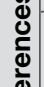 & $\frac{a}{s}$ & $\omega$ & $\stackrel{\infty}{+}$ & $\begin{array}{c}\stackrel{N}{\sim} \\
\stackrel{+}{+}\end{array}$ & 1 & $\omega$ & 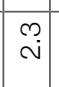 & $\underset{\sim}{\stackrel{\sim}{\sim}}$ & 1 & $r$ & $\stackrel{\infty}{\sim}$ & $\begin{array}{l}\infty \\
0 \\
\vdots \\
\vdots\end{array}$ & I & $\sigma$ & $\stackrel{\sim}{\sim}$ & $\begin{array}{c}\infty \\
\dot{0} \\
+\end{array}$ & \\
\hline 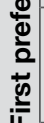 & 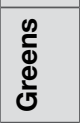 & $\sigma$ & 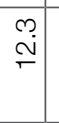 & $\begin{array}{l}\stackrel{m}{p} \\
\dot{p}\end{array}$ & 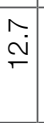 & $\sigma$ & $\begin{array}{l}\stackrel{+}{\dot{r}} \\
\end{array}$ & $\underset{i}{\stackrel{i}{i}}$ & $\begin{array}{l}\stackrel{\Upsilon}{F} \\
\dot{F}\end{array}$ & $\wedge$ & $\begin{array}{l}\stackrel{\sigma}{\dot{r}} \\
\dot{r}\end{array}$ & $\begin{array}{l}\sigma \\
\dot{T} \\
\end{array}$ & $\begin{array}{l}\infty \\
\infty \\
\sigma\end{array}$ & 으 & $\begin{array}{l} \\
\dot{\sigma}\end{array}$ & $\begin{array}{c}\overline{0} \\
\\
+\end{array}$ & $\begin{array}{l}\infty \\
\stackrel{\infty}{~}\end{array}$ \\
\hline 4 & 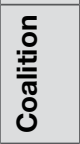 & ₹ & $\begin{array}{l}\sim \\
\dot{f}\end{array}$ & $\begin{array}{l}\hat{\alpha} \\
\bar{p} \\
\end{array}$ & $\begin{array}{l}\mathscr{g} \\
\dot{f}\end{array}$ & প్ల & $\begin{array}{l}\hat{\tilde{g}} \\
\dot{\gamma}\end{array}$ & $\stackrel{\sim}{\dot{P}}$ & 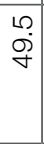 & $\stackrel{\varphi}{f}$ & $\begin{array}{l}\bar{r} \\
\dot{\gamma}\end{array}$ & $\bar{T}$ & $\begin{array}{l}\mathcal{\dot { f }} \\
\dot{f}\end{array}$ & 广 & $\begin{array}{l}0 \\
\dot{q} \\
\dot{q}\end{array}$ & & $\begin{array}{l}\check{r} \\
\stackrel{m}{c}\end{array}$ \\
\hline & $\frac{a}{\alpha}$ & $\stackrel{\infty}{\infty}$ & $\begin{array}{l}m \\
\stackrel{\infty}{\infty} \\
\tilde{m}\end{array}$ & $\begin{array}{l}\stackrel{\sim}{\dot{f}}+ \\
+\end{array}$ & 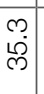 & ৫ & $\begin{array}{l} \\
\\
\end{array}$ & 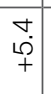 & $\begin{array}{l}\text { Ñ } \\
\text { ले }\end{array}$ & ₹ & $\begin{array}{l}\text { क्. } \\
\dot{m}\end{array}$ & $\begin{array}{r}\sigma \\
\dot{\sigma} \\
+\end{array}$ & $\begin{array}{l}\dot{0} \\
\dot{\phi} \\
\dot{\rho}\end{array}$ & ஜ & \begin{tabular}{|c|} 
\\
\end{tabular} & $\begin{array}{c}\hat{M} \\
\dot{P} \\
+\end{array}$ & $\stackrel{\nabla}{\grave{m}}$ \\
\hline $\begin{array}{l}\vec{\pi} \\
\stackrel{\pi}{\sharp}\end{array}$ & & & & & $\begin{array}{l}\frac{r}{\mathrm{O}} \\
\frac{\vec{D}}{0} \\
\frac{\pi}{I} \\
\end{array}$ & & & & 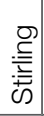 & & & & 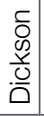 & & & & $\sum_{\substack{L \\
L}}^{\complement}$ \\
\hline í & & $\begin{array}{l}\overline{0} \\
0 \\
b\end{array}$ & $\begin{array}{l}0 \\
\stackrel{\sim}{N} \\
\stackrel{N}{2}\end{array}$ & 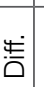 & $\begin{array}{l}0 \\
\stackrel{0}{2} \\
\text { v }\end{array}$ & $\begin{array}{l}\overline{\overline{0}} \\
\dot{b}\end{array}$ & $\begin{array}{l}0 \\
\grave{N}\end{array}$ & 苛 & 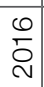 & $\begin{array}{l}\bar{E} \\
\underline{n}\end{array}$ & $\begin{array}{l}\text { o } \\
\stackrel{2}{N}\end{array}$ & 志 & $\begin{array}{l}0 \\
\grave{2} \\
\grave{N}\end{array}$ & $\begin{array}{l}\widetilde{\mathcal{V}} \\
\text { ve }\end{array}$ & $\begin{array}{l}0 \\
\mathbf{N} \\
\mathbf{N}\end{array}$ & 訔 & $\begin{array}{l}0 \\
\stackrel{2}{N}\end{array}$ \\
\hline & ֻٕ & & & & $\begin{array}{l}\frac{\widehat{\underline{m}}}{\mathrm{Z}} \\
\frac{\bar{z}}{3}\end{array}$ & & & & $\begin{array}{l}\frac{\widehat{D}}{2} \\
\frac{\pi}{3}\end{array}$ & & & & $\begin{array}{l}\frac{\tilde{y}}{z} \\
\frac{\partial}{0} \\
\frac{0}{\sigma}\end{array}$ & & & & $\begin{array}{l}\frac{\tilde{y}}{\partial} \\
\frac{\partial}{0} \\
\frac{\partial}{\alpha}\end{array}$ \\
\hline $\begin{array}{l}\overrightarrow{\tilde{\sigma}} \\
\frac{\bar{\sigma}}{U}\end{array}$ & & 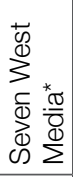 & & & & 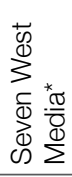 & & & & 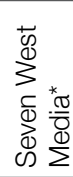 & & & & 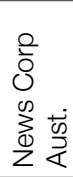 & & & \\
\hline 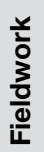 & & $\begin{array}{l}\sum_{10}^{\sqrt{0}} \\
\frac{10}{+1} \\
\frac{1}{d}\end{array}$ & & & & 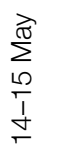 & & & & 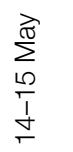 & & & & 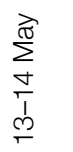 & & & \\
\hline
\end{tabular}


8. THE PERILOUS POLLING OF SINGLE SEATS

\begin{tabular}{|c|c|c|c|c|c|c|c|c|c|c|c|c|c|c|}
\hline \multirow{4}{*}{$\frac{a}{\sum_{2}}$} & 䓂 & & & $\begin{array}{l}\dot{0} \\
\dot{\varphi}\end{array}$ & & & & $\begin{array}{l}0 \\
0 \\
0 \\
1\end{array}$ & & & 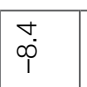 & & & \\
\hline & $\begin{array}{l}\overline{\mathrm{T}} \\
\text { 룽 }\end{array}$ & & $\begin{array}{l}0 \\
0 \\
0 \\
0\end{array}$ & & & & $\begin{array}{l}0 \\
0 \\
\infty \\
0\end{array}$ & & & & $\begin{array}{l}\nabla \\
\infty \\
\infty\end{array}$ & & & \\
\hline & 婳 & $\overrightarrow{ద ్}$ & & & & 8 & & & & 8 & & & & $\vec{b}$ \\
\hline & $\stackrel{0}{\circ}$ & & & & $\begin{array}{l}0 \\
\dot{0} \\
\dot{0}\end{array}$ & & & & $\begin{array}{l}\text { Oें } \\
\text { in }\end{array}$ & & & & 움 & \\
\hline$\Phi$ & 므 & $\overline{\mathbb{N}}$ & & & & $\sqrt{\sigma}$ & & & & $\Xi$ & & & & $\Xi$ \\
\hline ठే & $\underline{\underline{\Xi}}$ & & $\begin{array}{l} \\
\dot{0} \\
\dot{0}\end{array}$ & & $\bar{\omega}$ & & $\begin{array}{l}0 \\
\dot{\sigma}\end{array}$ & & $\begin{array}{l}\sigma \\
\dot{\theta}\end{array}$ & & \begin{tabular}{|l|}
0 \\
in \\
\end{tabular} & & 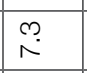 & \\
\hline \multirow{6}{*}{ 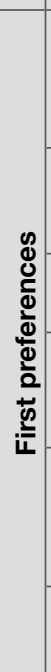 } & 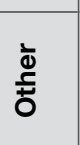 & $\sigma$ & $\begin{array}{l}0 \\
\dot{0}\end{array}$ & $\underset{+}{\stackrel{+}{+}}$ & $\begin{array}{c}\stackrel{+}{\circ} \\
\stackrel{2}{\circ}\end{array}$ & $\Gamma$ & 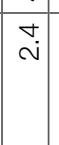 & 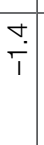 & 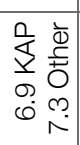 & 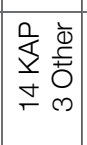 & 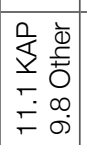 & 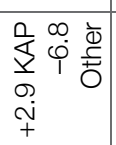 & 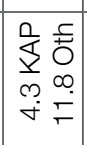 & 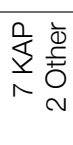 \\
\hline & $\begin{array}{l}z \\
\text { ơ } \\
\frac{1}{\alpha}\end{array}$ & $\Lambda$ & $\begin{array}{l}\stackrel{\leftrightarrow}{\oplus} \\
\stackrel{\sigma}{\leftarrow}\end{array}$ & $\begin{array}{l}\stackrel{0}{\mathrm{~N}} \\
\stackrel{T}{T}\end{array}$ & 1 & $\wedge$ & $\stackrel{\infty}{\stackrel{\infty}{+}}$ & $\begin{array}{l}\infty \\
\stackrel{+}{f}\end{array}$ & $\begin{array}{l}\stackrel{\rho}{\rho} \\
\stackrel{\rho}{\Gamma}\end{array}$ & 0 & $\check{F}$ & $\bar{\varphi}$ & $\stackrel{\circ}{\wedge}$ & $\nabla$ \\
\hline & $\frac{a}{s}$ & $\mp$ & $\stackrel{\stackrel{\sim}{*}}{+}$ & $\begin{array}{l}\infty \\
\dot{0} \\
+\end{array}$ & & 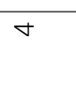 & $\check{f}^{-}$ & $\bar{\varphi}$ & ' & $\sigma$ & $\hat{\omega}$ & $\begin{array}{l}\stackrel{m}{\infty} \\
\stackrel{+}{+}\end{array}$ & ' & 10 \\
\hline & 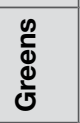 & $m$ & $\stackrel{\circ}{\dot{\rho}}$ & $\stackrel{\circ}{\circ}$ & \begin{tabular}{l|} 
\\
$\dot{\theta}$
\end{tabular} & 10 & $\begin{array}{l}\sim \\
\infty^{\circ}\end{array}$ & $\hat{\tilde{p}}$ & $\begin{array}{l}m \\
\oplus\end{array}$ & 10 & $\stackrel{M}{\wedge}$ & 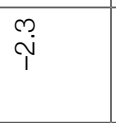 & $\begin{array}{l}\infty \\
\infty \\
\infty\end{array}$ & $\infty$ \\
\hline & 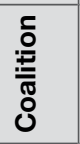 & $\hat{m}$ & $\begin{array}{l}0 \\
\stackrel{\infty}{\infty} \\
\end{array}$ & $\begin{array}{l}\text { Oे } \\
\dot{\varphi}\end{array}$ & \begin{tabular}{l|}
0 \\
$\dot{q}$ \\
$\dot{f}$
\end{tabular} & F & $\begin{array}{l}\dot{\omega} \\
\stackrel{\sim}{\sigma} \\
\end{array}$ & | & $\begin{array}{l}\text { L } \\
\stackrel{\infty}{\infty}\end{array}$ & ले & 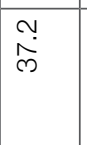 & $\stackrel{\sim}{\tilde{\varphi}}$ & $\begin{array}{l}\text { L } \\
\text { ه্ల }\end{array}$ & q \\
\hline & $\stackrel{\circ}{\frac{Q}{\alpha}}$ & m & $\hat{\sim}$ & $\begin{array}{l}0 \\
\stackrel{9}{+} \\
+\end{array}$ & \begin{tabular}{c|}
0 \\
$\dot{d}$ \\
$\dot{m}$
\end{tabular} & $\bar{\gamma}$ & $\begin{array}{l}0 \\
\stackrel{\circ}{N} \\
\stackrel{N}{*}\end{array}$ & $\begin{array}{l}0 \\
0 \\
0 \\
+ \\
+\end{array}$ & 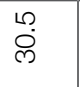 & ल & $\stackrel{\nabla}{\stackrel{D}{N}}$ & $\begin{array}{l}0 \\
\dot{\varphi} \\
+\end{array}$ & $\stackrel{\bar{\infty}}{\sim}$ & ले \\
\hline \multicolumn{2}{|l|}{ कू } & & & & $\begin{array}{l}\frac{0}{0} \\
\frac{0}{0} \\
\end{array}$ & & & & $\begin{array}{l}\frac{t}{0} \\
\frac{0}{\overline{0}} \\
\frac{1}{1}\end{array}$ & & & & $\begin{array}{l}\frac{1}{0} \\
\frac{0}{\pi} \\
\frac{\pi}{c} \\
\frac{0}{0} \\
1\end{array}$ & \\
\hline \multicolumn{2}{|c|}{$\dot{z}$} & $\begin{array}{l}\widehat{0} \\
i \underline{p}\end{array}$ & $\begin{array}{l}0 \\
\text { oे } \\
\text { ¿े }\end{array}$ & 䓂 & 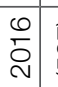 & $\begin{array}{l}\hat{\widehat{C}} \\
\hat{0} \\
\hat{b}\end{array}$ & 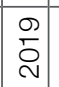 & 訔 & $\frac{0}{\grave{N}}$ & $\begin{array}{l}\bar{Q} \\
0,0\end{array}$ & $\stackrel{\text { Dे }}{\stackrel{\sim}{N}}$ & 訔 & $\frac{0}{2}$ & 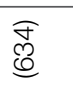 \\
\hline \multicolumn{2}{|c|}{ 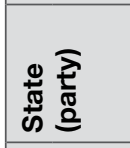 } & & & & \begin{tabular}{l|}
$\frac{a}{z}$ \\
$\frac{\partial}{0}$ \\
$\frac{0}{0}$
\end{tabular} & & & & $\begin{array}{l}\frac{a}{a} \\
\frac{1}{\Delta} \\
\frac{0}{0}\end{array}$ & & & & \begin{tabular}{|l}
$\frac{a}{1}$ \\
$\frac{1}{a}$ \\
$\frac{\partial}{0}$ \\
\end{tabular} & \\
\hline \multicolumn{2}{|c|}{$\begin{array}{l}\overrightarrow{\vec{\sigma}} \\
\frac{\overline{\underline{\sigma}}}{\bar{U}}\end{array}$} & 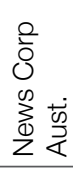 & & & & 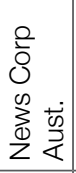 & & & & 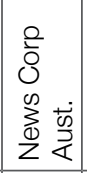 & & & 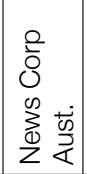 & \\
\hline \multicolumn{2}{|c|}{$\begin{array}{l}\frac{y}{0} \\
\frac{3}{0} \\
\frac{0}{0} \\
\frac{1}{4}\end{array}$} & 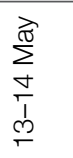 & & & & 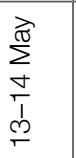 & & & & 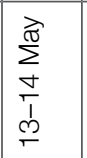 & & & 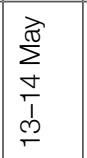 & \\
\hline
\end{tabular}


MORRISON'S MIRACLE

\begin{tabular}{|c|c|c|c|c|c|c|c|c|c|c|c|c|c|c|c|c|}
\hline \multirow{4}{*}{ 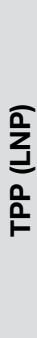 } & 杗 & & $\stackrel{\sim}{\oplus}$ & & & & $\begin{array}{l}\infty \\
\dot{p} \\
\dot{p}\end{array}$ & & & & $\overline{\widetilde{\top}}$ & & & & $\begin{array}{l}\stackrel{0}{\sim} \\
\dot{T}\end{array}$ & \\
\hline & 可。 & \begin{tabular}{l} 
N \\
\multirow{5}{*}{}
\end{tabular} & & & & $\begin{array}{l}\infty \\
\dot{f} \\
\dot{b}\end{array}$ & & & & 㝑 & & & & 足 & & \\
\hline & 芉 & & & & $\overrightarrow{i n}$ & & & & స్ర & & & & 8 & & & \\
\hline & ลั & & & 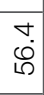 & & & & 它 & & & & 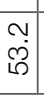 & & & & సิ่ \\
\hline \multirow{2}{*}{ 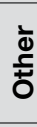 } & 号 & & & & $\widetilde{\mathbb{N}}$ & & & & $\Xi$ & & & & $\Xi$ & & & \\
\hline & $\underline{\underline{\Xi}}$ & $\stackrel{\nabla}{\bullet}$ & & $\stackrel{\circ}{\oplus}$ & & $F_{\dot{f}}$ & & $\begin{array}{l}\infty \\
\stackrel{\infty}{\infty}\end{array}$ & & $\stackrel{\mathrm{N}}{\mathrm{N}}$ & . & $\hat{\omega}$ & & \begin{tabular}{|l|}
0 \\
$\dot{\gamma}$
\end{tabular} & & \\
\hline \multirow{6}{*}{ 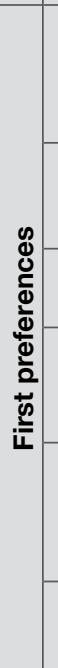 } & 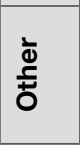 & 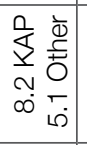 & 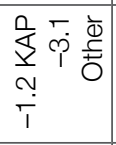 & $\begin{array}{c}m \\
\infty \\
\infty\end{array}$ & 0 & $\begin{array}{l}0 \\
\infty \\
\infty\end{array}$ & $\begin{array}{l}0 \\
\stackrel{\varphi}{i}\end{array}$ & $\stackrel{\wedge}{\wedge}$ & $\nabla$ & $\stackrel{\circ}{\dot{\rho}}$ & $\begin{array}{l}0 \\
\dot{+} \\
+\end{array}$ & 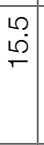 & $\infty$ & 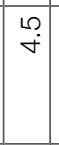 & $\begin{array}{l}0 \\
\stackrel{0}{0} \\
+ \\
+\end{array}$ & $\stackrel{\gamma}{\dot{\sigma}}$ \\
\hline & $\begin{array}{l}z \\
\text { ơ } \\
\text { T. }\end{array}$ & $\bar{\omega}$ & $\bar{\uparrow}$ & ' & 1 & 1 & 1 & ' & ' & 1 & 1 & 1 & ' & 1 & ' & $\begin{array}{l}\stackrel{\infty}{\dot{0}} \\
\stackrel{\infty}{\infty}\end{array}$ \\
\hline & $\frac{a}{s}$ & $\stackrel{\circ}{\circ}$ & $\underset{+}{\stackrel{+}{+}}$ & I & $\sigma$ & $\overline{\mathrm{N}}$ & $\underset{\sim}{\stackrel{\sim}{+}}$ & ' & $\nabla$ & $\stackrel{m}{\leftarrow}$ & $\begin{array}{c}\underset{\sim}{+} \\
+ \\
+\end{array}$ & 1 & $m$ & $\begin{array}{l} \\
\stackrel{0}{\mathrm{i}}\end{array}$ & $\begin{array}{l}+ \\
\dot{0} \\
+\end{array}$ & ' \\
\hline & 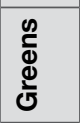 & $\begin{array}{l}\stackrel{+}{\circ} \\
\stackrel{\circ}{\circ}\end{array}$ & $\stackrel{⿱ 亠}{\top}$ & $\stackrel{m}{\Gamma}$ & $\sigma$ & $\begin{array}{l}\infty \\
\infty \\
\infty\end{array}$ & $\begin{array}{r}-\dot{+} \\
+ \\
+\end{array}$ & \begin{tabular}{l|l|} 
& \\
\multirow{d}{*}{} &
\end{tabular} & $\stackrel{N}{N}$ & $\stackrel{N}{\mathcal{N}}$ & $\begin{array}{l}0 \\
\dot{0} \\
+ \\
+\end{array}$ & $\begin{array}{l}m \\
\infty \\
\infty\end{array}$ & $\wedge$ & $\stackrel{\infty}{\wedge}$ & $\begin{array}{l}\infty \\
0 \\
0 \\
\end{array}$ & $\begin{array}{c}\infty \\
\infty\end{array}$ \\
\hline & 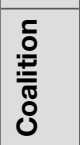 & $\begin{array}{l}\stackrel{0}{\stackrel{\rho}{M}} \\
\stackrel{M}{M}\end{array}$ & 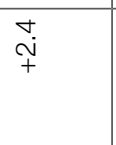 & $\begin{array}{l}m \\
0 \\
0 \\
0\end{array}$ & 寸 & $\begin{array}{l}\infty \\
\dot{f} \\
\dot{f}\end{array}$ & $\begin{array}{l}\infty \\
\dot{p} \\
\dot{p}\end{array}$ & $\begin{array}{l}0 \\
\dot{1} \\
\dot{1}\end{array}$ & \& & $\begin{array}{c}\sigma_{0}^{\prime} \\
\stackrel{\sigma}{\sigma}\end{array}$ & $\overline{\bar{p}} \bar{p}$ & $\bar{f}$ & \% & \begin{tabular}{|l|}
$\infty$ \\
$\dot{\rho}$ \\
$\dot{\rho}$
\end{tabular} & $\begin{array}{l}\infty \\
\stackrel{\infty}{+} \\
+\end{array}$ & זे \\
\hline & $\frac{2}{8}$ & $\begin{array}{l}\infty \\
\stackrel{\infty}{\infty} \\
\stackrel{\infty}{\infty}\end{array}$ & $\begin{array}{l}\text { N } \\
\stackrel{1}{+\infty} \\
+\end{array}$ & $\overline{\dot{m}}$ & $\hat{m}$ & $\begin{array}{c}0 \\
\dot{\omega} \\
\dot{m}\end{array}$ & $\stackrel{\stackrel{+}{+}}{+}$ & $\begin{array}{l} \\
0 \\
0 \\
0 \\
\end{array}$ & $\stackrel{\infty}{\sim}$ & $\begin{array}{l}\infty \\
\stackrel{\infty}{\sim}\end{array}$ & م. & $\bar{c}$ & க) & \begin{tabular}{|l|}
\multicolumn{1}{|c|}{} \\
लें
\end{tabular} & 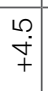 & 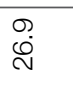 \\
\hline \multicolumn{2}{|l|}{ 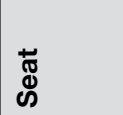 } & & & 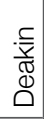 & & & & 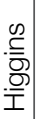 & & & & 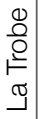 & & & & 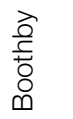 \\
\hline \multicolumn{2}{|c|}{$\dot{\text { ż }}$} & 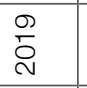 & 䓂 & 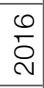 & 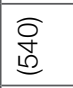 & $\begin{array}{l}0 \\
\stackrel{\sigma}{2}\end{array}$ & 䓂 & 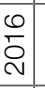 & 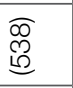 & 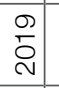 & 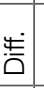 & $\begin{array}{l}0 \\
0 \\
\vdots \\
\end{array}$ & $\begin{array}{l}\text { 离 } \\
\text { 点 }\end{array}$ & 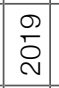 & 訔 & $\begin{array}{l}0 \\
\stackrel{0}{c} \\
\end{array}$ \\
\hline \multicolumn{2}{|c|}{ 造 } & & & $\begin{array}{l}\stackrel{\widehat{\underline{D}}}{\vec{\nu}} \\
\stackrel{\dot{j}}{>}\end{array}$ & & & & 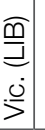 & & & & $\begin{array}{l}\widehat{\underline{\underline{m}}} \\
\stackrel{\dot{0}}{\mathrm{j}}\end{array}$ & & & & $\underset{\omega}{\stackrel{\widehat{\Phi}}{d}}$ \\
\hline \multicolumn{2}{|c|}{$\begin{array}{l}\frac{\vec{\tau}}{\Phi} \\
\frac{\bar{\sigma}}{\mathrm{U}}\end{array}$} & & & & 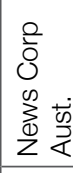 & & & & 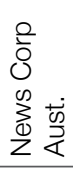 & & & & $\begin{array}{l}\frac{0}{0} \\
0 \\
0 \\
\sum_{0}^{\infty} \\
\frac{0}{2} \frac{\dot{m}}{2}\end{array}$ & & & \\
\hline \multicolumn{2}{|c|}{ 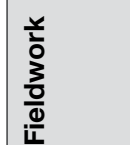 } & & & & 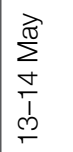 & & & & 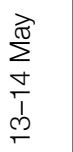 & & & & 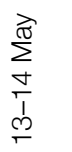 & & & \\
\hline
\end{tabular}


8. THE PERILOUS POLLING OF SINGLE SEATS

\begin{tabular}{|c|c|c|c|c|c|c|c|c|c|c|c|c|c|c|c|c|c|}
\hline \multirow{4}{*}{$\begin{array}{l}\frac{a}{n} \\
己 \\
0 \\
0 \\
\underline{r}\end{array}$} & 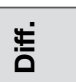 & & & $\begin{array}{l}0 \\
\stackrel{\varphi}{+} \\
+\end{array}$ & & & & & 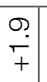 & & & & $\begin{array}{l}0 \\
\dot{p} \\
1\end{array}$ & & & & \\
\hline & 䟰 & & $\frac{\nabla}{\square}$ & & $\overleftarrow{\circlearrowleft}$ & & & $\bar{\circ}$ & & & & $\begin{array}{l}0 \\
0 \\
0 \\
0\end{array}$ & & & & & $\begin{array}{l}\stackrel{\circ}{\circ} \\
\stackrel{f}{\gamma}\end{array}$ \\
\hline & 䓵 & लె口 & & & $\overleftarrow{\circlearrowleft}$ & & $\vec{i}$ & & & & लె & & & & & $\overrightarrow{⿱ 亠}+\underset{+}{ }$ & \\
\hline & $\frac{0}{0}$ & & & & ర্ & 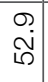 & & & & $\begin{array}{l}\vec{\nabla} \\
\dot{\circ}\end{array}$ & & & & & $\begin{array}{l}\hat{\circ} \\
\dot{\circ}\end{array}$ & & \\
\hline \multirow{2}{*}{ } & 产 & $\overline{\mathbb{N}}$ & & & & & $\Xi$ & & & & $\overline{\mathbb{N}}$ & & & & & $\overline{\mathbb{V}}$ & \\
\hline & $\underline{\underline{\Xi}}$ & & $\stackrel{\gamma}{\forall}$ & & & & & $\overline{\dot{m}}$ & & & & $\begin{array}{l}\overrightarrow{0} \\
\dot{0}\end{array}$ & & & $\dot{\sigma}$ & & $\stackrel{\sim}{\sim}$ \\
\hline \multirow{6}{*}{ 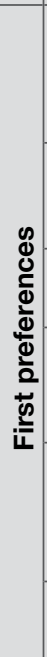 } & 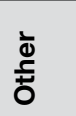 & $\nabla$ & $\begin{array}{l}3 \\
0\end{array}$ & $\begin{array}{c}m \\
\stackrel{N}{N} \\
\end{array}$ & & $\begin{array}{l}\varphi \\
\dot{0}\end{array}$ & $\sim$ & $\begin{array}{l}O \\
\stackrel{O}{*}\end{array}$ & I & $\begin{array}{l}\infty \\
\dot{\forall}\end{array}$ & $\infty$ & $\begin{array}{l}\circ \\
\dot{0}\end{array}$ & $\begin{array}{c}\stackrel{\bigcirc}{\mathrm{j}} \\
+\end{array}$ & & $\begin{array}{l}\circ \\
\stackrel{\circ}{\circ}\end{array}$ & $\infty$ & $\begin{array}{l}\infty \\
\infty \\
\infty\end{array}$ \\
\hline & $\begin{array}{l}z \\
\text { 으 } \\
\text { T. } \\
\end{array}$ & ' & ' & 1 & & $\begin{array}{l}\text { के } \\
\text { ले }\end{array}$ & $\stackrel{\mathscr{P}}{\forall}$ & $\begin{array}{l}\stackrel{N}{\dot{m}} \\
\stackrel{\text { S }}{1}\end{array}$ & $\begin{array}{c}\infty \\
\infty \\
+\end{array}$ & $\begin{array}{l}\stackrel{\oplus}{\sigma} \\
\stackrel{\circ}{\square}\end{array}$ & 1 & 1 & ' & zo & ' & ' & ' \\
\hline & $\frac{0}{s}$ & $m$ & $\stackrel{\rho}{\leftarrow}$ & $\begin{array}{l}\overline{-} \\
+ \\
\end{array}$ & & 1 & $m$ & $\begin{array}{c}N \\
\dot{m}\end{array}$ & $\begin{array}{l}\text { No } \\
0 \\
1\end{array}$ & ' & $\sigma$ & $\begin{array}{l}\stackrel{\sim}{\sim} \\
\end{array}$ & $\begin{array}{l}0 \\
\dot{0} \\
+ \\
\end{array}$ & & I & $\sim$ & $\stackrel{\forall}{\stackrel{\nabla}{c}}$ \\
\hline & 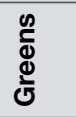 & a & 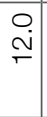 & $\begin{array}{l}0 \\
\dot{p} \\
p\end{array}$ & & $\bar{\infty}$ & $\Lambda$ & $\begin{array}{l}m \\
\dot{\sigma}\end{array}$ & $\stackrel{m}{\sim}$ & $\begin{array}{l}0 \\
\sim\end{array}$ & 0 & $\begin{array}{l}\sim \\
\mp \\
\mp\end{array}$ & $\begin{array}{c}\sim \\
\stackrel{p}{p} \\
\dot{p}\end{array}$ & & $\begin{array}{l}\stackrel{0}{0} \\
\stackrel{0}{\circ}\end{array}$ & $\Lambda$ & $\begin{array}{l}\infty \\
\dot{\sigma}\end{array}$ \\
\hline & 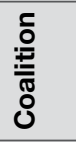 & f & 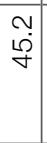 & $\begin{array}{l}\infty \\
\\
+\infty \\
+ \\
+\end{array}$ & & $\begin{array}{l}\text { के } \\
\text { ले }\end{array}$ & $\stackrel{\infty}{\infty}$ & $\begin{array}{l}\hat{\lambda} \\
\hat{M}\end{array}$ & $\begin{array}{l}0 \\
0 \\
0 \\
+\end{array}$ & $\begin{array}{l}\stackrel{+}{*} \\
\dot{J}\end{array}$ & ํ & $\begin{array}{l}0 \\
0 \\
0 \\
1\end{array}$ & $\begin{array}{l}0 \\
\infty \\
1\end{array}$ & & $\begin{array}{l}m \\
\stackrel{\rho}{\sigma}\end{array}$ & 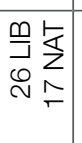 & 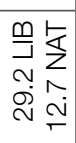 \\
\hline & $\frac{0}{4}$ & $\hat{\infty}$ & $\begin{array}{l}0 \\
\dot{\text { ले }}\end{array}$ & $\begin{array}{l}\underset{+}{\stackrel{v}{*}} \\
+\end{array}$ & & $\begin{array}{l}\hat{\theta} \\
\underline{6}\end{array}$ & $\wedge$ & $\begin{array}{l}\hat{m} \\
\vec{\sigma}\end{array}$ & $\begin{array}{l}\hat{\varphi} \\
\dot{\varphi}\end{array}$ & $\begin{array}{l}\stackrel{v}{N} \\
\stackrel{N}{N}\end{array}$ & $\stackrel{\infty}{\infty}$ & $\begin{array}{l}\text { O } \\
\stackrel{\sim}{N}\end{array}$ & $\begin{array}{c}\bar{i} \\
+ \\
+\end{array}$ & & ণ্ & 아 & $\begin{array}{l}\text { N } \\
\ddot{\infty}\end{array}$ \\
\hline \multicolumn{2}{|c|}{$\begin{array}{l}\text { 苂 } \\
\stackrel{\Phi}{\infty}\end{array}$} & & & & & 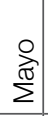 & & & & $\begin{array}{l}\frac{5}{7} \\
\stackrel{\leftrightarrows}{\omega}\end{array}$ & & & & & $\begin{array}{l}\frac{0}{0} \\
\frac{E}{\overline{0}}\end{array}$ & & \\
\hline \multicolumn{2}{|c|}{ ì } & $\begin{array}{l}\text { त्रे } \\
\text { in }\end{array}$ & $\stackrel{\circ}{\circ}$ & 䓂 & & 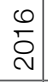 & 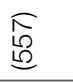 & $\begin{array}{c}\infty \\
\bar{N}\end{array}$ & 萑 & 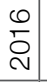 & 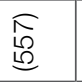 & $\begin{array}{l}\infty \\
\stackrel{\sim}{N}\end{array}$ & 米 & & $\frac{0}{2}$ & $\begin{array}{l}\text { D } \\
\text { b } \\
\underline{0}\end{array}$ & $\stackrel{\circ}{\stackrel{2}{\alpha}}$ \\
\hline \multicolumn{2}{|c|}{ 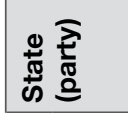 } & & & & & 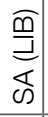 & & & & 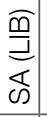 & & & & & 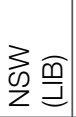 & & \\
\hline \multicolumn{2}{|c|}{$\begin{array}{l}\frac{\vec{c}}{\Phi} \\
\frac{\bar{U}}{U}\end{array}$} & 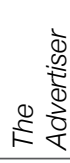 & & & & & 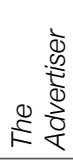 & & & & 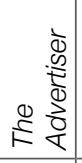 & & & & & 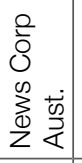 & \\
\hline \multicolumn{2}{|c|}{$\begin{array}{l}\frac{y}{2} \\
\frac{3}{0} \\
\frac{0}{0} \\
\frac{1}{4}\end{array}$} & $\sum_{0}^{\vec{\pi}}$ & & & & & $\sum_{\sim}^{\stackrel{\varpi}{\sigma}}$ & & & & 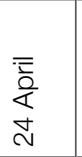 & & & & & 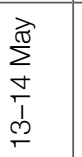 & \\
\hline
\end{tabular}


MORRISON'S MIRACLE

\begin{tabular}{|c|c|c|c|c|c|c|c|c|c|c|c|}
\hline \multirow{4}{*}{$\begin{array}{l}\frac{a}{z} \\
z \\
\frac{a}{n} \\
r\end{array}$} & 䓂 & $\begin{array}{l}0 \\
0 \\
+\end{array}$ & & & & 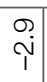 & & & & $\frac{N}{T}$ & \\
\hline & 预 & & & & $\begin{array}{l}\stackrel{\circ}{8} \\
\stackrel{8}{+}\end{array}$ & & & & $\begin{array}{l}\stackrel{N}{\infty} \\
\tilde{N}\end{array}$ & & \\
\hline & 崩 & & & $\vec{\forall}$ & & & & $\overrightarrow{\mathrm{N}}$ & & & \\
\hline & $\stackrel{\circ}{\circ}$ & & $\begin{array}{l}\infty \\
\stackrel{+}{F}\end{array}$ & & & & $\stackrel{\sim}{\dot{\sigma}}$ & & & & \\
\hline \multirow{2}{*}{ के } & 高 & & & $\Xi$ & & & & $\sqrt{0}$ & & & \\
\hline & $\stackrel{\leftrightarrows}{\underline{\Xi}}$ & & $\begin{array}{l}0 \\
0 \\
0\end{array}$ & & $\stackrel{\rho}{\sim}$ & & $\begin{array}{l}0 \\
\circ\end{array}$ & & $\overline{0}$ & & \\
\hline \multirow{6}{*}{$\begin{array}{l}0 \\
0 \\
0 \\
\frac{0}{0} \\
\frac{0}{0} \\
\frac{4}{0} \\
\frac{0}{2} \\
\overline{0} \\
\frac{0}{1}\end{array}$} & 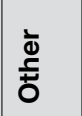 & $\begin{array}{l}\infty \\
\dot{p}\end{array}$ & $\underset{\Gamma}{\stackrel{\Gamma}{\sigma}}$ & $\sim$ & $\hat{ल}$ & 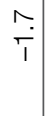 & $\stackrel{\nabla}{0}$ & $\wedge$ & $\stackrel{L}{\sigma}$ & $\begin{array}{l}\stackrel{0}{0} \\
\underset{+}{+}\end{array}$ & \\
\hline & $\begin{array}{l}z \\
\text { 움 } \\
\text { 음 }\end{array}$ & ' & ' & 1 & 1 & 1 & 1 & ' & 1 & 1 & \\
\hline & 足 & $\frac{⿱}{\dot{r}}$ & 1 & 10 & $\stackrel{\circ}{\circ}$ & $\begin{array}{l}\stackrel{0}{\circ} \\
+\dot{+}\end{array}$ & 1 & 0 & $\stackrel{\leftrightarrow}{\rightarrow}$ & $\stackrel{\ulcorner}{+}$ & \\
\hline & 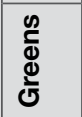 & $\begin{array}{l}\infty \\
\stackrel{1}{\top}\end{array}$ & $\begin{array}{l}\stackrel{\sim}{\mp} \\
\ulcorner\end{array}$ & $\infty$ & $\bar{\sigma}$ & $\bar{r}_{\bar{T}}$ & $\begin{array}{l}10 \\
\infty \\
\infty\end{array}$ & $\wedge$ & $\sigma_{\infty}$ & $\bar{r}_{\bar{T}}$ & \\
\hline & 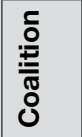 & 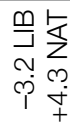 & $\begin{array}{l}\stackrel{N}{0} \\
\infty \\
\infty\end{array}$ & $\stackrel{\vartheta}{f}$ & $\begin{array}{l}\text { O } \\
\dot{\nabla}\end{array}$ & 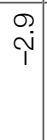 & $\begin{array}{l}\infty \\
\infty \\
\stackrel{\infty}{+}\end{array}$ & $\underset{\forall}{ }$ & \begin{tabular}{|l|} 
\\
$\infty$ \\
$\infty$ \\
$q$ \\
\end{tabular} & $\begin{array}{l}\stackrel{m}{+} \\
\stackrel{T}{+}\end{array}$ & \\
\hline & $\frac{9}{\frac{1}{<}}$ & $\begin{array}{l}\infty \\
\dot{\infty} \\
+\end{array}$ & $\begin{array}{l}\stackrel{L}{\infty} \\
\stackrel{\rho}{\infty}\end{array}$ & $\mathscr{P}$ & $\begin{array}{l}\infty \\
\infty \\
\infty \\
\infty\end{array}$ & $\begin{array}{l}\hat{+} \\
\dot{+} \\
+\end{array}$ & $\begin{array}{l}m \\
\dot{e}\end{array}$ & @) & $\begin{array}{l}N \\
\stackrel{n}{\infty}\end{array}$ & $\frac{N}{1}$ & \multirow{6}{*}{ 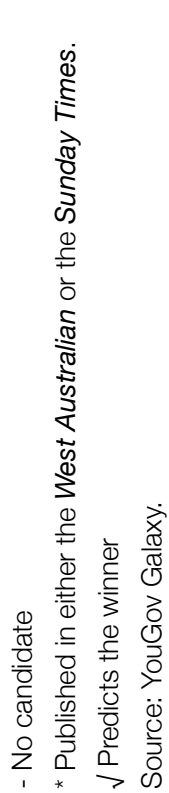 } \\
\hline ल & & & 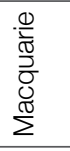 & & & & $\begin{array}{l}\frac{0}{0} \\
\simeq \\
\simeq\end{array}$ & & & & \\
\hline í & & 市 & $\stackrel{0}{\circ}$ & $\begin{array}{l}\overline{9} \\
\stackrel{5}{0} \\
\end{array}$ & $\frac{\pi}{2}$ & 岕 & $\frac{0}{\grave{\alpha}}$ & $\begin{array}{l}\text { D } \\
\stackrel{+}{0} \\
\end{array}$ & 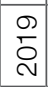 & 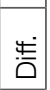 & \\
\hline \multicolumn{2}{|c|}{ 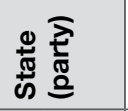 } & & 忿品 & & & & 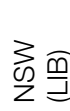 & & & & \\
\hline \multicolumn{2}{|l|}{ 蒙 } & & 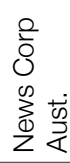 & & & & 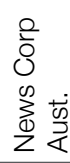 & & & & \\
\hline \multicolumn{2}{|c|}{$\begin{array}{l}\frac{Y}{2} \\
\frac{3}{0} \\
\frac{0}{0} \\
\frac{1}{4}\end{array}$} & & 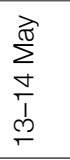 & & & & 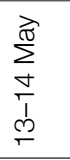 & & & & \\
\hline
\end{tabular}


8. THE PERILOUS POLLING OF SINGLE SEATS

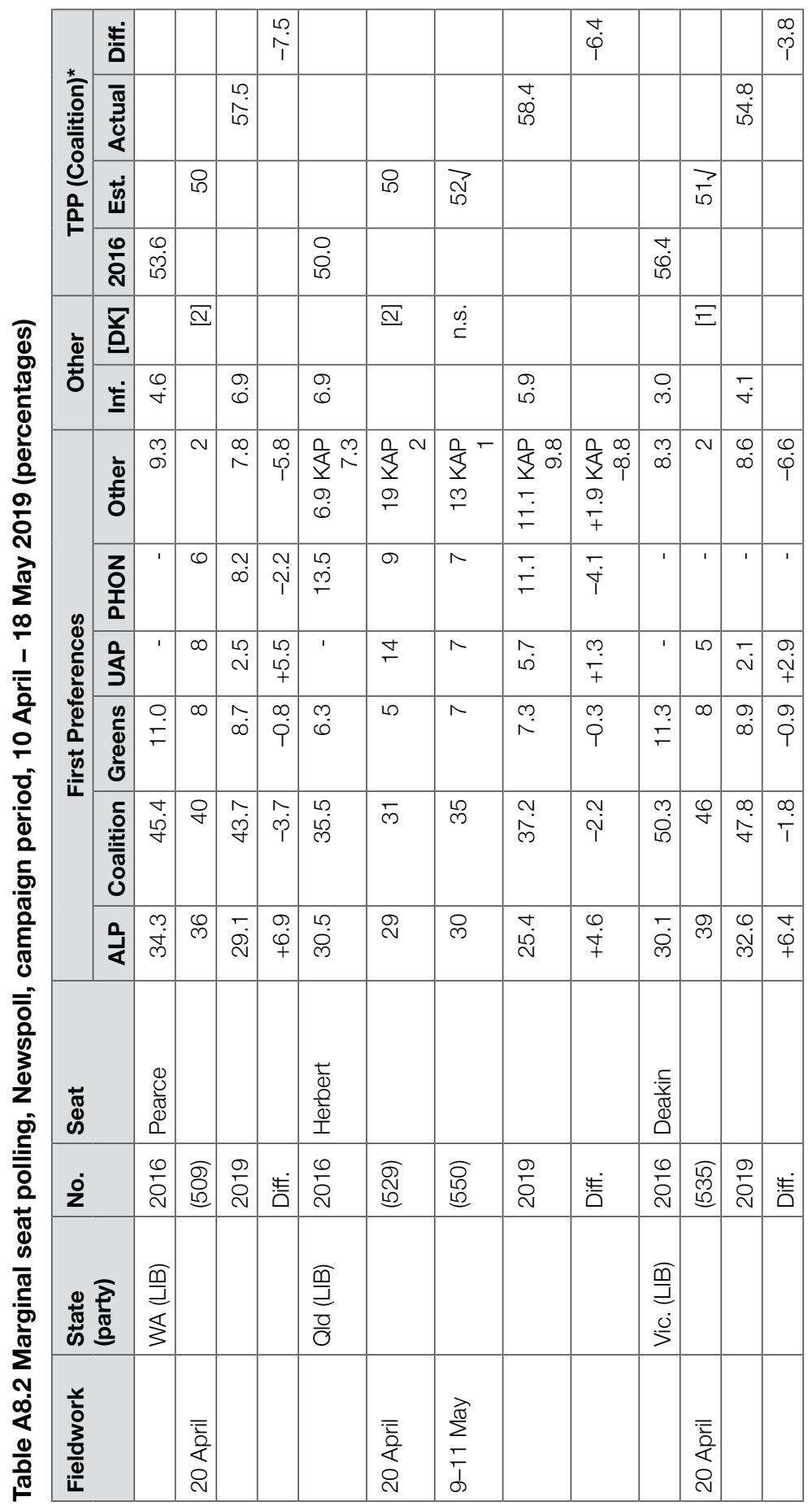




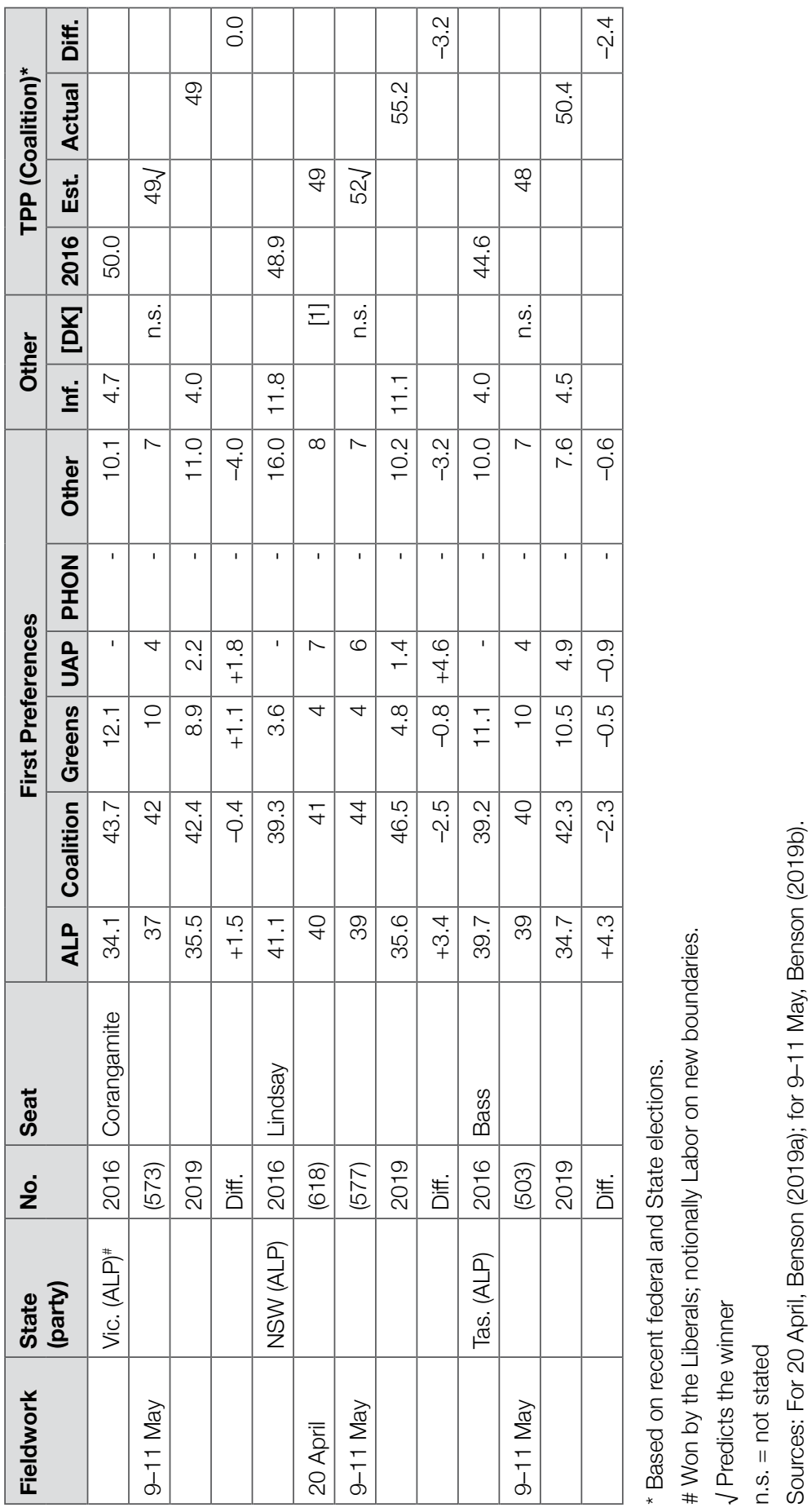




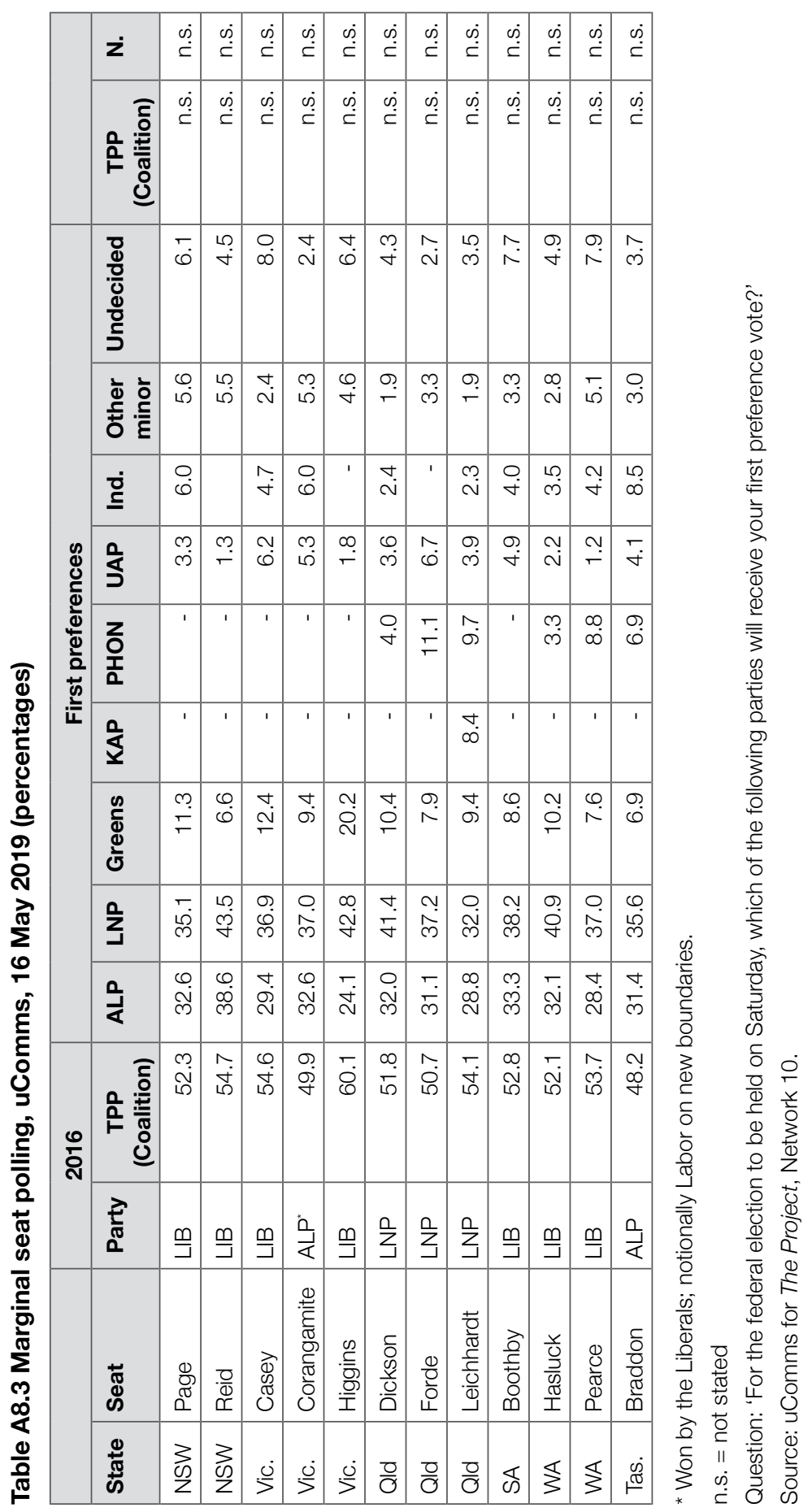




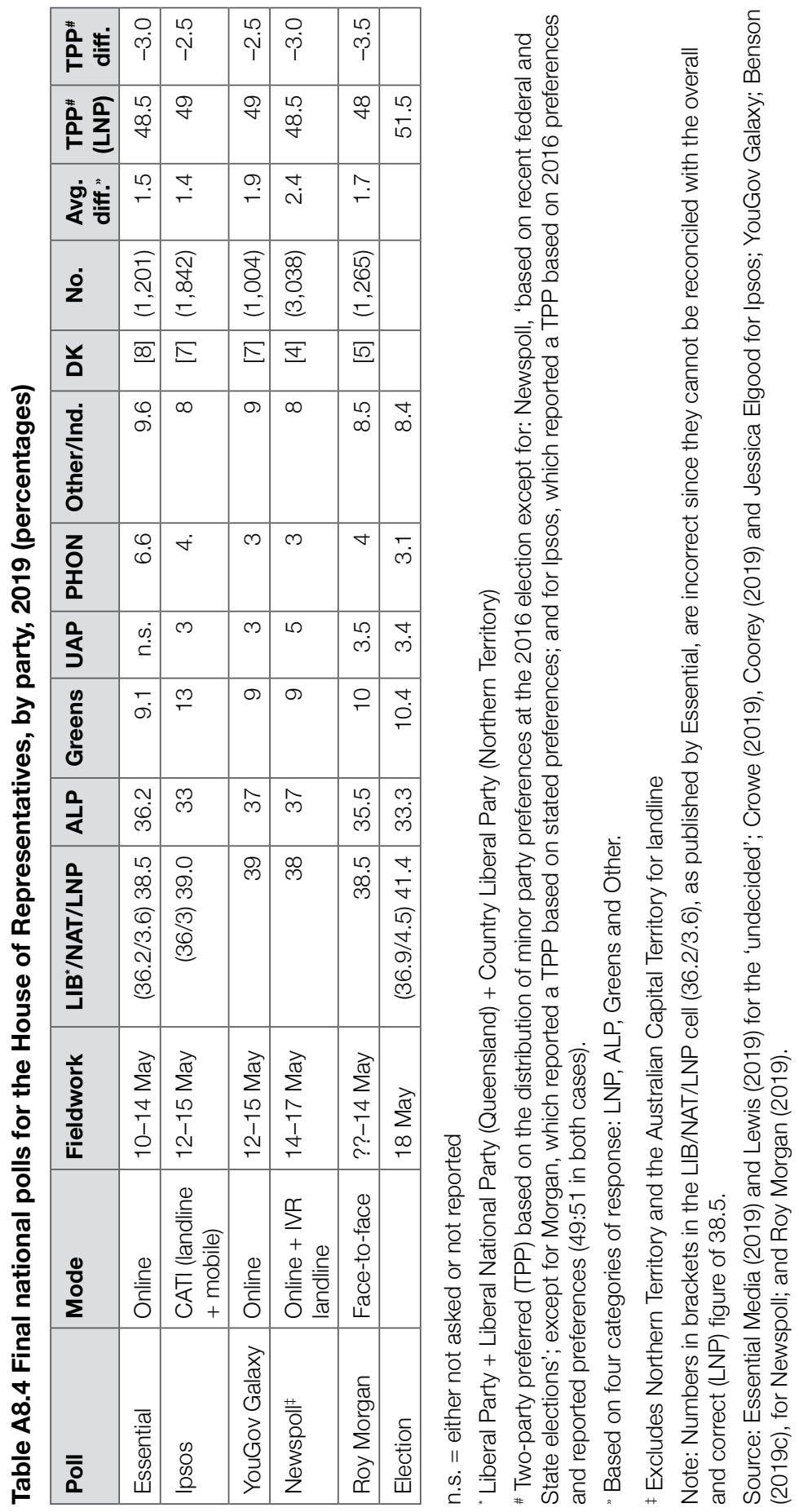


This text is taken from Morrison's Miracle: The 2019 Australian Federal Election, edited by Anika Gauja, Marian Sawer and Marian Simms, published 2020 by ANU Press, The Australian National University, Canberra, Australia.

doi.org/10.22459/MM.2020.08 